\title{
Volatile and intermediate volatility organic compounds in suburban Paris: variability, origin and importance for SOA formation
}

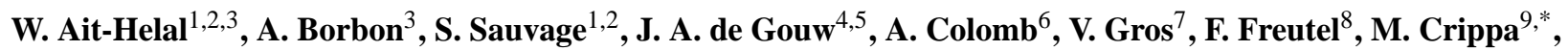 \\ C. Afif ${ }^{3,10}$, U. Baltensperger ${ }^{9}$, M. Beekmann ${ }^{3}$, J.-F. Doussin ${ }^{3}$, R. Durand-Jolibois ${ }^{3}$, I. Fronval ${ }^{1,2}$, N. Grand ${ }^{3}$, \\ T. Leonardis ${ }^{1,2}$, M. Lopez ${ }^{7}$, V. Michoud ${ }^{3}$, K. Miet ${ }^{3}$, S. Perrier ${ }^{3, * *}$, A. S. H. Prévôt ${ }^{9}$, J. Schneider ${ }^{8}$, G. Siour ${ }^{3}$, P. Zapf ${ }^{3}$, \\ and N. Locoge $\mathrm{e}^{1,2}$ \\ ${ }^{1}$ Université Lille Nord de France, 59000, Lille, France \\ ${ }^{2}$ École des Mines de Douai, Département Chimie et Environnement, 59508 Douai CEDEX, France \\ ${ }^{3}$ LISA, UMR-CNRS 7583, Université Paris Est Créteil (UPEC), Université Paris Diderot (UPD), Institut Pierre Simon \\ Laplace (IPSL), Créteil, France \\ ${ }^{4}$ Chemical Sciences Division, Earth System Research Laboratory, NOAA, Boulder, Colorado, USA \\ ${ }^{5}$ Cooperative Institute for Research in Environmental Sciences, University of Colorado, Boulder, Colorado, USA \\ ${ }^{6}$ LaMP, UMR-CNRS 6016, Clermont Université, Université Blaise Pascal, Aubière, France \\ ${ }^{7}$ LSCE, CNRS 8212, CEA, Université de Versailles Saint-Quentin en Yvelines, Gif sur Yvette, France \\ ${ }^{8}$ Max Planck Institute for Chemistry, Mainz, Germany \\ ${ }^{9}$ Laboratory of Atmospheric Chemistry, Paul Scherrer Institute, Villigen, Switzerland \\ ${ }^{10}$ Centre d'Analyses et de Recherche, Faculty of sciences, Université Saint Joseph, Beirut, Lebanon \\ * now at: EC Joint Research Centre (JRC), Inst. Environment \& Sustainability, Via Fermi, 2749, 21027 Ispra, Italy \\ ** now at : ISA, UMR-CNRS 5280, Université Lyon 1, ENS-Lyon, Villeurbanne, France
}

Correspondence to: A. Borbon (agnes.borbon@lisa.u-pec.fr)

Received: 9 January 2014 - Published in Atmos. Chem. Phys. Discuss.: 21 February 2014

Revised: 17 July 2014 - Accepted: 7 August 2014 - Published: 1 October 2014

\begin{abstract}
Measurements of gaseous and particulate organic carbon were performed during the MEGAPOLI experiments, in July 2009 and January-February 2010, at the SIRTA observatory in suburban Paris. Measurements comprise primary and secondary volatile organic compounds (VOCs), of both anthropogenic and biogenic origins, including $\mathrm{C}_{12}-\mathrm{C}_{16} n$ alkanes of intermediate volatility (IVOCs), suspected to be efficient precursors of secondary organic aerosol (SOA). The time series of gaseous carbon are generally consistent with times series of particulate organic carbon at regional scale, and are clearly affected by meteorology and air mass origin. Concentration levels of anthropogenic VOCs in urban and suburban Paris were surprisingly low (2-963 ppt) compared to other megacities worldwide and to rural continental sites. Urban enhancement ratios of anthropogenic VOC pairs agree well between the urban and suburban Paris sites, showing the regional extent of anthropogenic sources of similar composition. Contrary to other primary anthropogenic
\end{abstract}

VOCs (aromatics and alkanes), IVOCs showed lower concentrations in winter $(<5 \mathrm{ppt})$ compared to summer (13$27 \mathrm{ppt}$ ), which cannot be explained by the gas-particle partitioning theory. Higher concentrations of most oxygenated VOCs in winter (18-5984 ppt) suggest their dominant primary anthropogenic origin. The respective role of primary anthropogenic gaseous compounds in regional SOA formation was investigated by estimating the SOA mass concentration expected from the anthropogenic VOCs and IVOCs (I / VOCs) measured at SIRTA. From an integrated approach based on emission ratios and SOA yields, $38 \%$ of the SOA measured at SIRTA is explained by the measured concentrations of I/VOCs, with a $2 \%$ contribution by $\mathrm{C}_{12}-\mathrm{C}_{16}$ $n$-alkane IVOCs. From the results of an alternative timeresolved approach, the average IVOC contribution to SOA formation is estimated to be $7 \%$, which is half of the average contribution of the traditional aromatic compounds $(15 \%)$. Both approaches, which are based on in situ observations 
of particular I / VOCs, emphasize the importance of the intermediate volatility compounds in the SOA formation, and support previous results from chamber experiments and modeling studies. They also support the need to make systematic the IVOCs' speciated measurement during field campaigns.

\section{Introduction}

Since 1950, the number of people living in urban areas has steadily increased. According to the United Nations, the urban population has risen from 30 to $50 \%$ of the world population within the last 50 years, and it will reach about $70 \%$ by 2050 (United Nations, 2012). This intensive urbanization has led to the development of numerous megacities, defined as urban centers with at least 10 million inhabitants. If a high population density characterizes a megacity, they are also defined by their anthropogenic activities, which are not different from other urban centers but more intense; larger amounts of atmospheric pollutants are emitted in megacities. Among them, there are the volatile organic compounds (VOCs), the emissions of which are diverse and include both anthropogenic and biogenic sources. In urban areas like megacities, where industrialization and traffic are important (Molina and Molina, 2004), VOCs are mainly emitted by primary anthropogenic sources (Gros et al., 2007). Once emitted into the atmosphere, primary VOCs can be photolyzed or/and oxidized by atmospheric oxidants like the hydroxyl radical $(\mathrm{OH})$, the nitrate radical $\left(\mathrm{NO}_{3}\right)$ or ozone $\left(\mathrm{O}_{3}\right)$, and then, other VOCs are produced (Atkinson and Arey, 2003). These newly produced VOCs or secondary VOCs, generally oxygenated (OVOC), can themselves undergo further reactions and produce different oxidants as by-products, including ozone (Jenkin and Hayman, 1999; Tanaka et al., 2003), whose adverse effects on climate and people are well-known (Heiden et al., 1999; Wildt et al., 2003; Filleul et al., 2006).

VOCs in megacities have been widely studied in the past. Their ambient concentrations have been commonly explored (Barletta et al., 2002; Khoder, 2007), but numerous studies mainly focused on traffic emissions (Baumbach et al., 1995; Colón et al., 2001; Barletta et al., 2002; Srivastava et al., 2005; Martins et al., 2007; Khillare et al., 2008; Majumdar et al., 2008). VOC emissions by other sources (solvent uses, gasoline evaporation, gas leakage, etc.) were also investigated, especially through source apportionment studies (Srivastava, 2004; Lanz et al., 2008; Bon et al., 2011; Gaimoz et al., 2011). As for biogenic VOCs, even though their emissions are not as strong in urban areas, their study remains of great importance in such areas, since they can contribute to the formation of secondary gaseous pollutants, including ozone (Chameides et al., 1988; Shao et al., 2000; Duan et al., 2008; Ran et al., 2011).

Oxidation of VOCs leads to the formation of other gaseous compounds. Also, organic aerosols (OA) can result from these reactions (Kanakidou et al., 2005; Hallquist et al., 2009). Just like VOCs, organic aerosols can be directly emitted into the atmosphere - they are then called primary organic aerosol particles (POA), or they can be formed from VOC precursors, whose oxidation products are partitioned between the particulate and the gaseous phases; they are then defined as secondary organic aerosol particles (SOA) (Odum et al., 1997; Kanakidou et al., 2005). In either of the two phases, some organic pollutants are known to be harmful to people, threatening their health (Magill, 1949; Dockery et al., 1993; Finkelstein et al., 2004; Kappos et al., 2004; Anderson, 2009). They also play a role in the climate change, impacting the visibility and earth's radiation balance (Park et al., 2003; Kanakidou et al., 2005).

Important uncertainties concerning the sources, formation and fate of the organic aerosol particles are still to be addressed. In order to fill gaps in the knowledge of aerosols, and especially of secondary aerosols, one needs to rely on chamber experiments, field measurements and modeling. Chamber experiments allowed for the study of SOA yields, resulting from the oxidation of individual VOCs. Several classes of species have been identified as important SOA precursors, in particular terpenes and aromatic compounds (Seinfeld and Pandis, 1998; Lee et al., 2006a; Ng et al., 2007a, b). Combined with these SOA yields, field measurements of both VOCs and organic aerosols have permitted the evaluation of the effective contribution of the measured VOCs to the observed SOA (de Gouw et al., 2005, 2008). Finally, predictive models have been developed from observations in the field and in the laboratory. In urban areas, estimations using these models often led to a large underestimation of observed SOA: de Gouw et al. (2008) explained only $37 \%$ of the measured SOA in New England, USA, while Volkamer et al. (2006) underestimated observed SOA by a factor of 10 by using a gas-particle partitioning model. This discrepancy increased downwind of the sources, and a factor of up to 100 could be reached in remote areas (Heald et al., 2005). De Gouw et al. (2008) suggested a strong role of non-measured gaseous carbon, especially those of low volatility, as an explanation of this discrepancy. Indeed, until recently, biogenic VOCs were thought to be the main SOA precursors (Kanakidou et al., 2005). However, in urban areas, this assumption has since been refuted (Volkamer et al., 2006; Hodzic et al., 2010) and has been found true only in clean atmospheres, where the prediction of SOA formation appears to be accurate (Hodzic et al., 2009). Hodzic et al. (2010) recently improved the SOA prediction in urban areas by considering primary gaseous organic compounds of lower volatility, which could partition between the gas and the particulate phase (Robinson et al., 2007; Epstein et al., 2010; Zhang et al., 2013). Recently, laboratory studies as well as field measurements have indeed highlighted the importance of VOCs of lower volatility in the SOA formation in urban areas (Robinson et al., 2007; Coe, 2011; Li et al., 2013; Yuan et al., 2013) and downwind of a well-defined crude oil spill (de Gouw et 
al., 2011), emphasizing the need to measure these species. Even though major progress has been made in the understanding of SOA formation and the role of the IVOCs, the studies rarely reproduce the conditions encountered in urban areas. Indeed, laboratory studies for the determination of the SOA yields only investigate SOA formed by the oxidation of a single IVOC precursor (Lim and Ziemann, 2005, 2009a, b; Chan et al., 2009; Presto et al., 2010). As for the in situ studies, they have only considered a single IVOC source (Robinson et al., 2007; de Gouw et al., 2011; Li et al., 2013).

In this context, the FP7 MEGAPOLI project (Megacities: Emissions, urban, regional and Global Atmospheric POLlution and climate effects, and Integrated tools for assessment and mitigation) aims to quantify sources of primary and secondary aerosols and the role of organic gas-phase precursors in and around a large metropolitan area, and to describe their evolution in the megacity plume. Two intensive field campaigns were conducted in the Greater Paris region during summer 2009 and winter 2010, during which simultaneous measurements of gaseous and particulate organic compounds were performed. A wide range of gaseous carbonaceous compounds, from $\mathrm{C}_{1}$ to $\mathrm{C}_{16}$, was measured at a suburban site of Paris (SIRTA), including important SOA precursors such as the $\mathrm{C}_{6}-\mathrm{C}_{8}$ aromatic compounds, monoterpenes and the $\mathrm{C}_{12}-\mathrm{C}_{16} n$-alkanes of intermediate volatility, which are rarely measured in an ambient atmosphere. Measurements of VOCs $\left(\mathrm{C}_{2}-\mathrm{C}_{6}\right.$ and $\left.\mathrm{C}_{6}-\mathrm{C}_{10}\right)$ at an urban background site (LHVP) were also performed.

The first goal of this paper is to analyze the temporal and spatial variability and origin of gaseous organic carbon in suburban Paris. The respective role of chemical removal, primary and secondary emissions and meteorology is discussed (Sects. 3 and 4). The second goal of this paper is to estimate the respective contribution of the anthropogenic VOC precursors to the SOA formation in summertime, with a particular focus on the importance of the $n$-alkanes of intermediate volatility (Sect. 5). The method relies on two independent approaches: an integrated approach and a time-resolved approach.

\section{Methods}

\subsection{Sampling sites}

One summertime and one wintertime field campaign were conducted in Paris and its surrounding area in the frame of the EU-MEGAPOLI project. The first experiment took place during the whole month of July 2009; the second one started on 15 January 2010 and ended on 15 February 2010.

Measurements of the gaseous organic carbon were performed at two ground sites: SIRTA and LHVP, which are presented in Fig. 1. SIRTA, which stands for "Site Instrumental de Recherche par Télédétection Atmosphérique", is located in Palaiseau $\left(48.713^{\circ} \mathrm{N}, 2.214^{\circ} \mathrm{E} ; 156 \mathrm{~m}\right.$ above sea

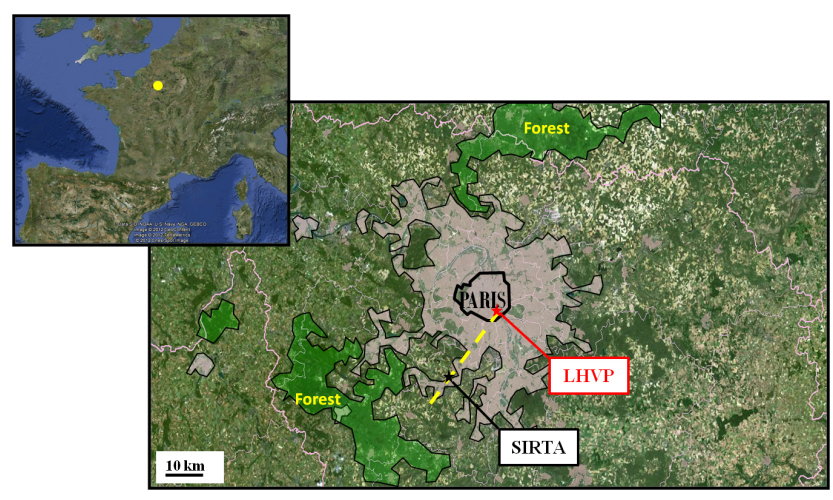

Figure 1. MEGAPOLI sampling sites (source: Google Earth).

level), $14 \mathrm{~km}$ southwest of Paris. This site, surrounded by fields, wooded areas, houses and industries, has been qualified as suburban (Haeffelin et al., 2005). LHVP ("Laboratoire d'Hygiène de la Ville de Paris", $48.829^{\circ} \mathrm{N}, 2.207^{\circ} \mathrm{E}$; $62 \mathrm{~m}$ above sea level) is an urban background site located in the southern part of the French capital. The sampling site is located in a large public garden at approximately $150 \mathrm{~m}$ from a major street. Due to the low intensity of the surrounding traffic and from measurements, it has been qualified as representative of Paris background pollution (Favez et al., 2007; Sciare et al., 2010; Gros et al., 2011).

This article focuses on the gaseous and particulate organic carbon measured at SIRTA. Measurements performed at LHVP are used here to support the analysis of the organic carbon at SIRTA.

\subsection{Measurements of organic carbon and ancillary data}

The organic carbon was intensively measured at the two sites, in both the gaseous and particulate phases, using numerous offline and online instruments. All the instruments used in the present analysis and their performances are presented in Tables 1 and 2.

At SIRTA, gaseous organic carbon measurements included $\mathrm{C}_{1}-\mathrm{C}_{16}$ organic compounds. These compounds can be classified according to their saturation concentration, $C^{*}$, which is an indicator of their volatility (Robinson et al., 2007; Epstein et al., 2010). Thus, given their $C^{*}, \mathrm{C}_{12}-\mathrm{C}_{16} n$ alkanes are of intermediate volatility, as they are characterized by $10^{3} \mu \mathrm{g} \mathrm{m}^{-3}<C^{*}<10^{6} \mu \mathrm{g} \mathrm{m}^{-3}$, while all other measured compounds were volatile $\left(C^{*}>10^{6} \mu \mathrm{g} \mathrm{m}^{-3}\right.$ ) (Robinson et al., 2007; de Gouw et al., 2011). It should be noted that, in this paper, the acronyms IVOCs and VOCs will be used to designate each family, while I/VOCs will include both of them. $\mathrm{C}_{1}-\mathrm{C}_{16}$ organic compounds were collected by active sampling on sorbent cartridges, using a sampling module developed by TERA Environment - either a SASS (Smart Automatic Sampling System) in summer or an ACROSS (Automatic Clean ROom Sampling System) in winter (Detournay et al., 2011). Gaseous compounds were 
Table 1. Offline measurements of the gaseous organic carbon during MEGAPOLI at SIRTA.

\begin{tabular}{|c|c|c|c|c|c|c|}
\hline Column compounds & Column sorbent & Institution & Analysis & LOD (ppt) & Uncertainty (\%) & Reference \\
\hline $\begin{array}{l}\text { Aromatics } \\
\mathrm{C}_{9}-\mathrm{C}_{16} \text { alkanes } \\
\mathrm{C}_{9}-\mathrm{C}_{10} \text { aldehydes } \\
\text { Terpenes }\end{array}$ & $\begin{array}{l}\text { Activated charcoal } \\
\text { (carbotrap B + car- } \\
\text { botrap C) }\end{array}$ & EMD/LISA & $\begin{array}{l}\text { Adsorption/thermal } \\
\text { desorption (ATD) } \\
+ \text { GC-FID }\end{array}$ & $1-20$ & $3-26$ & $\begin{array}{l}\text { Detournay et } \\
\text { al. }(2011)\end{array}$ \\
\hline $\begin{array}{l}\mathrm{C}_{1}-\mathrm{C}_{9} \text { aldehydes Ke- } \\
\text { tones }\end{array}$ & $\begin{array}{l}2,4- \\
\text { dinitrophenylhydrazin } \\
\text { (DNPH) }\end{array}$ & EMD/LISA & $\begin{array}{l}\text { Chemical desorp- } \\
\text { tion (acetonitrile) } \\
+ \text { HPLC/UV }\end{array}$ & $10-60$ & $11-37$ & $\begin{array}{l}\text { Kleindienst } \\
\text { et al. (1998) } \\
\text { Bates et al. (2000) } \\
\text { Dettmer and Enge- } \\
\text { wald (2003) }\end{array}$ \\
\hline
\end{tabular}

LOD: limit of detection

Table 2. Online measurements of organic carbon and ancillary data during MEGAPOLI at SIRTA and LHVP.

\begin{tabular}{|c|c|c|c|c|c|c|c|}
\hline Measurements & Site & Institution & Instrument & $\begin{array}{l}\text { Time resolution } \\
(\mathrm{min})\end{array}$ & $\begin{array}{l}\text { LOD } \\
(\mathrm{ppt})\end{array}$ & $\begin{array}{l}\text { Uncertainty } \\
(\%)\end{array}$ & Reference \\
\hline $\mathrm{C}_{3}-\mathrm{C}_{9} \mathrm{NMHCs}$ & SIRTA & LISA & $\begin{array}{l}\text { GC-FID AirmoVOC } \\
\left(\text { Chromatotec }{ }^{\circledR}\right)\end{array}$ & 30 & 100 & 20 & \\
\hline $\begin{array}{l}\mathrm{C}_{2}-\mathrm{C}_{6} \mathrm{NMHCs} \\
\mathrm{C}_{6}-\mathrm{C}_{10} \text { NMHCs }\end{array}$ & LHVP & LSCE & $\begin{array}{l}2 \quad \text { GC-FIDs } \\
\left(\text { Chromatotec }^{\circledR}\right)\end{array}$ & 30 & $37-93$ & $15-20$ & Gros et al. (2011) \\
\hline $\mathrm{CO}$ & SIRTA & LSCE & $\begin{array}{l}\text { GC (hot mercuric oxide } \\
\text { detection) }\end{array}$ & 15 & 1000 & 10 & Gros et al. (1999) \\
\hline NO & SIRTA & LISA & $\begin{array}{l}\text { AC31M analyzer (En- } \\
\text { vironnement S.A.) }\end{array}$ & 1 & 500 & 5 & \\
\hline $\mathrm{NO}_{2}$ & SIRTA & LISA & $\mathrm{NO}_{\mathrm{x}} \mathrm{TOy}$ (MetAir) & 1 & 500 & 5 & $\begin{array}{l}\text { Dommen et al. (2000) } \\
\text { Michoud et al. (2012) }\end{array}$ \\
\hline $\mathrm{O}_{3}$ & SIRTA & LISA & $\begin{array}{l}\text { 49C analyzer (Thermo } \\
\text { Environment Instru- } \\
\text { ment) }\end{array}$ & 1 & 1000 & 5 & \\
\hline $\begin{array}{l}\text { Meteorological } \\
\text { parameters } \\
\text { ( } T, \mathrm{RH}, \mathrm{P} \text {, speed and } \\
\text { direction of the wind) }\end{array}$ & SIRTA & LISA & $\begin{array}{l}\text { Wind sensor and multi- } \\
\text { plate radiation shield } \\
\text { (Young) }\end{array}$ & 1 & NA & NA & \\
\hline Mixing layer depth & SIRTA & LMD & ALS450 Lidar & 60 & NA & NA & Haeffelin et al. (2012) \\
\hline $\begin{array}{l}\text { Non-refractory par- } \\
\text { ticulate matter }\left(\mathrm{PM}_{1}\right)\end{array}$ & SIRTA & PSI & HR-ToF-AMS & 5 & NA & $30-36$ & $\begin{array}{l}\text { DeCarlo et al. (2006) } \\
\text { Crippa et al. (2013a) } \\
\text { Freutel et al. (2013a) }\end{array}$ \\
\hline
\end{tabular}

LOD: limit of detection.

sampled at approximately $4 \mathrm{~m}$ above ground level (a.g.1.), and then trapped into one of the two types of cartridges: a multi-sorbent cartridge, composed of carbopack C (200 mg) and carbopack B (200 mg) (carbotrap ${ }^{\mathrm{TM}} 202$ from PerkinElmer ${ }^{\circledR}$ ), and a Sep-Pak DNPH-Silica cartridge (Waters ${ }^{\circledR}$ ). $\mathrm{C}_{6}-\mathrm{C}_{8}$ aromatic compounds, $\mathrm{C}_{9}-\mathrm{C}_{16} n$-alkanes, monoterpenes and $\mathrm{C}_{6}-\mathrm{C}_{10} n$-aldehydes were sampled during 3 hours at a flow rate of $200 \mathrm{~mL} \mathrm{~min}^{-1}$ on the multi-sorbent cartridges. Additional $\mathrm{C}_{1}$ to $\mathrm{C}_{9}$ OVOCs (oxygenated VOCs) were sampled onto the DNPH-cartridges, with a time resolution of 3 hours too but at a flow rate of $1.5 \mathrm{~L} \mathrm{~min}^{-1}$. Prior to sampling, carbotrap ${ }^{\mathrm{TM}}$-filled cartridges were conditioned with purified air at $250^{\circ} \mathrm{C}$, at a flow rate of $10 \mathrm{~mL} \mathrm{~min}^{-1}$, during $24 \mathrm{~h}$. During the sampling, different ozone scrubbers were used in order to prevent any ozonolysis of the measured compounds: a KI ozone scrubber was installed upstream of the sampling onto DNPH cartridges, while a
$\mathrm{MnO}_{2}$ ozone scrubber was used for the cartridges filled with carbotrap $^{\mathrm{TM}}$. Besides, stainless-steel particle filters of $2 \mu \mathrm{m}$ porosity (Swagelok ${ }^{\circledR}$ ) were used to prevent any sampling of particles, which could block the sampling system. Cartridges were then analyzed by HPLC/UV (High-Performance Liquid Chromatography with Ultra Violet detection; for the DNPH cartridges) or by GC-FID (Gas Chromatography coupled to a Flame Ionization Detector; for the carbotrap ${ }^{\text {TM }}$ filled cartridges) in the laboratory. The reproducibility of the analysis was checked by the daily analysis of a standard, leading to the plotting of a control chart for each compound, which allowed the reproducibility of the instruments to be checked.

At SIRTA, online measurements of $\mathrm{C}_{3}-\mathrm{C}_{9} \mathrm{NMHCs}$ (nonmethane hydrocarbons) were also performed using an autosampling GC-FID, AirmoVOC (Chromatotec ${ }^{\circledR}$ ). Two other auto-sampling GC-FIDs were installed at LHVP: ChromaTrap and AirmoBTX (both from Chromatotec ${ }^{\circledR}$ ) for the 
$\mathrm{C}_{2}-\mathrm{C}_{6}$ and the $\mathrm{C}_{6}-\mathrm{C}_{10}$ NMHCs measurements, respectively. Details on the latter instruments can be found in Gros et al. (2011). Inlet lines of the instruments were located at 4 and $15 \mathrm{~m}$ a.g.l. at SIRTA and LHVP stations, respectively.

Carbon monoxide was measured at SIRTA by a Gas Chromatograph coupled to a Reduction Gas Analyzer (Trace Analytical, Menlo Park, CA, USA), following the method described by Gros et al. (1999). Calibration was performed with a $40 \mathrm{~L}$ aluminum cylinder $\mathrm{CO}$ standard gas $(187 \pm 20 \mathrm{ppb})$ in synthetic air, which was provided and calibrated by the Central Calibration Laboratories (CCL) of the National Oceanic and Atmospheric Administration (NOAA, Boulder, CO, USA) (Novelli et al., 1994). CO measurements were performed every $2.5 \mathrm{~min}$, by alternating injection of a standard and of a sample (atmospheric air). Each sample was calibrated against the preceding standard and measurements were averaged every $15 \mathrm{~min}$.

The chemical composition of submicron particulate organic carbon $\left(\mathrm{PM}_{1}\right)$ was investigated with a High Resolution Time-of-Flight Aerosol Mass Spectrometer (HR-ToF-AMS) at each site (Crippa et al., 2013a; Freutel et al., 2013a). A positive matrix factorization (PMF) analysis was used for the organic fraction of the particulate matter in order to identify the different components of the organic matter (OM) (Crippa et al., 2013a, b; Freutel et al., 2013a).

Complementary measurements of nitrogen oxide (NO) and nitrogen dioxide $\left(\mathrm{NO}_{2}\right)$, as well as of ozone $\left(\mathrm{O}_{3}\right)$ were performed at SIRTA. Temperature, wind speed and direction, relative humidity, solar radiation and pressure were measured by a weather station (see details in Table 2).

FLEXPART simulations were computed on a $3 \mathrm{~h}$ basis for the two campaigns. Based on a Lagrangian particle dispersion model, FLEXPART simulations provide information on the probable origin of particles and trace gases sampled at the receptor site by looking at the dispersion of air pollutants (Stohl et al., 2005).

\section{Overview of the VOCs measurements}

\subsection{Seasonal variations of VOCs}

Table 3 summarizes the means and the standard deviations of the concentrations of the VOCs measured at SIRTA during the summertime and wintertime MEGAPOLI campaigns and their properties. Data below the limit of detection (LOD) were replaced by LOD/2. It can be seen that the VOC mean concentrations exhibit high relative standard deviations, ranging from 50 to $100 \%$, caused by the high variability of the compounds during the two campaigns as a consequence of the changes in synoptic meteorology and air mass origin (Crippa et al., 2013a; Freutel et al., 2013a).

VOCs of anthropogenic origin, including aromatics and $\mathrm{C}_{4}-\mathrm{C}_{6}$ alkanes, have higher mixing ratios in winter. This difference can be explained by three factors (Boudries et al.,
1994; Cheng et al., 1997; Na and Kim, 2001; Swanson et al., 2003; Yang et al., 2005; Shirai et al., 2007): (i) a stronger temperature inversion in winter than in summer, leading to a mean daytime boundary layer 3 times shallower in winter than in summer at SIRTA $(440 \pm 220 \mathrm{~m}$ and $1340 \pm 610 \mathrm{~m}$, respectively, between 9 a.m. and 6 p.m.) (Filella and Peñuelas, 2006); (ii) lower $\mathrm{OH}$ radical concentrations in winter and thus less depletion by photochemistry (Michoud et al., 2012, 2014); and finally (iii) sources of different nature, composition and/or strengths. Different primary anthropogenic sources are known to be subject to the seasonal variations detailed in the last assumption, among these is the fuel evaporation. Indeed, seasonal modifications in the fuel formulation reduce the fraction of the light VOCs (butanes and pentanes) in summer to limit fuel evaporation (Borbon et al., 2003; Lee et al., 2006b; Gentner et al., 2009). Engine cold-start emissions also vary seasonally: they are enhanced in winter as a consequence of low temperatures, which results in the stronger emission of aromatic compounds in vehicular exhaust during winter (Heeb et al., 1999; Borbon et al., 2002; Hoque et al., 2008; Roukos et al., 2009). Finally, the cold weather in winter leads to an intensive use of domestic heating and thus to increased emissions of toluene, benzene or even butane (e.g., Borbon et al., 2002; Badol et al., 2008; Roukos et al., 2009).

Similarly, the light $\mathrm{C}_{2}-\mathrm{C}_{6}$ oxygenated VOCs (methylvinylketone (MVK) and methylethylketone (MEK) excluded) also have higher mixing ratios in winter, indicating that OVOC are dominated by primary anthropogenic emissions such as traffic (Grosjean et al., 2001; Legreid et al., 2007) or wood burning (Schauer et al., 2001; Gaeggeler et al., 2008). These observations contrast with previous studies that have found higher OVOC concentrations in summer at urban and suburban sites (Sin et al., 2001; Ho et al., 2002; Bakeas et al., 2003; Legreid et al., 2007; Wang, 2010) as a consequence of their enhanced photochemical secondary production in summer.

On the contrary, VOCs of biogenic origin (isoprene and pinenes) show higher levels in summer due to their temperature-dependent biogenic emissions. Isoprene emissions have the particularity to also be light dependent (Guenther et al., 1991). This is also observed for MVK for which isoprene is the precursor. Limonene and camphene exhibit different behaviors compared to other terpenes. Limonene, which does not vary seasonally, and camphene are still detected in winter. Measurements of monoterpenes (pinenes, camphene and limonene) in urban areas are not common, unlike for isoprene which is also known to be emitted by primary anthropogenic sources (Borbon et al., 2001). Monoterpene measurements are usually performed in remote areas, far from any anthropogenic influence (Kleindienst et al., 2007; Detournay et al., 2013). To our knowledge, only Yoshino et al. (2012) measured them individually in an urban area, Tokyo (Japan), during the two seasons. They found higher concentrations in winter than in summer for the 
Table 3. Summer and winter mean concentrations, standard deviation (SD), percentage of values below limit of detection ( $\%<$ LOD), rate constant with $\mathrm{OH}(\mathrm{kOH}$; when not indicated: Atkinson and Arey, 2003) and SOA yield formation (when not indicated: Seinfeld and Pandis, 1998) of the VOCs measured in suburban Paris (SIRTA).

\begin{tabular}{|c|c|c|c|c|c|c|}
\hline \multirow[t]{2}{*}{ Compound } & \multicolumn{2}{|c|}{ Summer (ppt) } & \multicolumn{2}{|c|}{ Winter (ppt) } & \multirow{2}{*}{$\frac{10^{12} k_{\mathrm{OH}}(298 \mathrm{~K})}{\left(\mathrm{cm}^{3} \text { molecule }^{-1} \mathrm{~s}^{-1}\right)}$} & \multirow{2}{*}{$\frac{\text { SOA Yield }}{\left(\mu \mathrm{g} \mathrm{m}^{-3} \mathrm{ppm}^{-1}\right)}$} \\
\hline & Mean & $\mathrm{SD}(\%<\mathrm{LOD})$ & Mean & $\mathrm{SD}(\%<\mathrm{LOD})$ & & \\
\hline$i$-Butane & 250 & $140(0)$ & 460 & $282(0)$ & 2.12 & 0 \\
\hline$n$-Butane & 377 & $393(0)$ & 963 & $588(0)$ & 2.3 & 0 \\
\hline$i$-Pentane & 334 & $354(11)$ & 416 & $213(0)$ & 3.6 & - \\
\hline$n$-Pentane & 193 & $138(27)$ & nd & nd & 3.8 & 0 \\
\hline Hexane & 94 & $50(66)$ & 85 & $50(13)$ & 5.2 & - \\
\hline Nonane & 14 & $13(0)$ & 18 & $13(0)$ & 9.7 & $425^{d}$ \\
\hline Decane & 24 & $22(11)$ & 24 & $19(0)$ & 11 & $850^{d}$ \\
\hline Undecane & 19 & $16(1)$ & 16 & $11(0)$ & 12.3 & $1726^{\mathrm{d}}$ \\
\hline Dodecane & 22 & $21(0)$ & 7 & $4(5)$ & 13.2 & $258^{\mathrm{e}} ; 1136^{\mathrm{f}}$ \\
\hline Tridecane & 13 & $12(56)$ & 2 & $1(41)$ & 15.1 & $754^{\mathrm{e}} ; 2896^{\mathrm{f}}$ \\
\hline Tetradecane & 27 & $23(0)$ & 2 & $2(63)$ & $17.9(312 \mathrm{~K})$ & $1152^{\mathrm{e}} ; 3887^{\mathrm{f}}$ \\
\hline Pentadecane & 23 & $18(0)$ & 4 & $2(8)$ & $20.7(312 \mathrm{~K})$ & $1416^{\mathrm{e}} ; 4622^{\mathrm{f}}$ \\
\hline Hexadecane & 22 & $19(6)$ & nd & nd & $23.2(312 \mathrm{~K})$ & $1750^{\mathrm{e}} ; 5214^{\mathrm{f}}$ \\
\hline Isoprene & 357 & $280(5)$ & 69 & $39(4)$ & 100 & $64^{g}$ \\
\hline$\alpha$-Pinene & 48 & $45(0)$ & 20 & $52(25)$ & 52.3 & $2338^{\mathrm{h}}$ \\
\hline$\beta$-Pinene & 10 & $6(4)$ & nd & nd & 74.3 & $1724^{\mathrm{i}}$ \\
\hline Camphene & nd & nd & 23 & $18(1)$ & 53 & 762 \\
\hline Limonene & 16 & $16(7)$ & 15 & $19(1)$ & 164 & $3283^{\mathrm{i}}$ \\
\hline Benzene & NA & NA & 316 & $155(0)$ & 1.22 & $1181^{\mathrm{j}} ; 898^{\mathrm{j}}$ \\
\hline Toluene & 207 & $179(0)$ & 321 & $216(0)$ & 5.63 & $1145^{\mathrm{j}} ; 404^{\mathrm{j}}$ \\
\hline Ethylbenzene & 37 & $31(0)$ & 60 & $39(0)$ & 7 & $1145^{\mathrm{j}, \mathrm{k}} ; 404^{\mathrm{j}, \mathrm{k}}$ \\
\hline m,p-Xylene & 80 & $76(0)$ & 150 & $109(0)$ & $23.1 ; 14.3$ & $1578^{\mathrm{j}} ; 276^{\mathrm{j}}$ \\
\hline o-Xylene & 40 & $31(0)$ & 53 & $39(0)$ & 13.6 & $1578^{\mathrm{j}, \mathrm{k}} ; 276^{\mathrm{j}, \mathrm{k}}$ \\
\hline Formaldehyde & 1607 & $1031(0)$ & 5984 & $1892(0)$ & 9.37 & 0 \\
\hline Acetaldehyde & 621 & $283(0)$ & 1199 & $528(0)$ & 15 & - \\
\hline Acetone & 1344 & $480(0)$ & 1705 & $677(0)$ & 0.17 & 0 \\
\hline Glyoxal & 47 & $23(1)$ & 158 & $119(5)$ & 11 & 0 \\
\hline Methylglyoxal & 55 & $38(15)$ & 207 & $153(9)$ & 15 & 0 \\
\hline Propanal & 85 & $42(3)$ & 247 & $125(0)$ & 20 & - \\
\hline Methylvinylketone (MVK) & 290 & $273(3)$ & 54 & $108(12)$ & 20 & - \\
\hline Butenal & 8 & $4(100)$ & 860 & $593(1)$ & $36.0^{\mathrm{a}}$ & - \\
\hline Butan-2-one (MEK) & 1639 & $1500(0)$ & 363 & $262(6)$ & 1.22 & 0 \\
\hline Methacrolein & 60 & $63(19)$ & 121 & $178(25)$ & 29 & - \\
\hline$i, n$-Butanal & 52 & $31(24)$ & 318 & $310(3)$ & $24-26$ & - \\
\hline$i$-Pentanal & 15 & $14(85)$ & 77 & $45(26)$ & 27 & - \\
\hline Benzaldehyde & 26 & $16(25)$ & 638 & $301(2)$ & 12 & - \\
\hline Pentanal + o-tolualdehyde & 29 & $12(69)$ & 84 & $60(35)$ & $28 ; 18$ & - \\
\hline m,p-Tolualdehyde & 8 & $4(100)$ & 25 & $22(87)$ & $17 ; 13$ & - \\
\hline 2,5-Dimethylbenzaldehyde & 7.5 & $11(93)$ & 412 & $253(6)$ & $43.7^{\mathrm{b}}$ & - \\
\hline Hexanal & 54 & $50(7)$ & 31 & $27(2)$ & 30 & - \\
\hline Heptanal & 67 & $68(2)$ & 46 & $26(0)$ & 30 & - \\
\hline Octanal & 82 & $66(2)$ & nd & nd & $28.6^{\mathrm{c}}$ & - \\
\hline Nonanal & 58 & $45(2)$ & 18 & $14(8)$ & $30.0^{c}$ & - \\
\hline Decanal & 39 & $22(2)$ & nd & nd & $31.4^{\mathrm{c}}$ & - \\
\hline
\end{tabular}

NA: not available; nd: not detected; ${ }^{\mathrm{a}}$ : Atkinson, $1986 ;{ }^{\mathrm{b}}$ : Tse et al. (1997); ${ }^{\mathrm{c}}$ : Hellén et al. (2004); ${ }^{\mathrm{d}}$ : Lim and Ziemann (2009a); ${ }^{\mathrm{e}}$ : Presto et al. (2010), $C_{\mathrm{OA}}=2 \mu \mathrm{g} \mathrm{m}^{-3}$; ${ }^{\mathrm{f}}$.

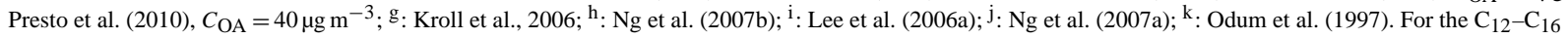
$n$-alkanes and the aromatics, the first SOA yield values is the one determined under relevant atmospheric conditions to our study, the second one is the one determined under both high $C_{\mathrm{OA}}$ and high $\mathrm{NO}_{\mathrm{x}}$. 
pinenes, with concentrations of $\beta$-pinene lower than those of $\alpha$-pinene, which is in good agreement with our measurements. Camphene concentrations were equal to zero during the two seasons, while limonene concentrations were slightly more important in winter than in summer. Finally, our results, supported by those of Yoshino et al. (2012), suggest weaker sink processes in winter than in summer. Our results also imply a small anthropogenic source in urban/suburban areas of these compounds, in addition to their well-known biogenic origin. This latter assumption has been recently put forward by Hellén et al. (2012), who identified traffic and wood combustion as potential emission sources of VOCs formerly thought to be only of biogenic origin.

The $\mathrm{C}_{12}-\mathrm{C}_{16}$ IVOCs alkanes have higher mixing ratios in summer than in winter, whereas the other compounds, the $\mathrm{C}_{6}-\mathrm{C}_{10}$ aldehydes and the $\mathrm{C}_{9}-\mathrm{C}_{11} n$-alkanes, do not show any clear seasonality in their mixing ratios. The IVOCs alkanes, which can be emitted by traffic (Fraser et al., 1998; Schauer et al., 1999a, 2002), cooking activities (Schauer et al., 1999b) or biomass burning (Schauer et al., 2001), are more likely to be subject to their partitioning between the gas- and the particle-phase, which could explain the seasonal differences. Indeed, measurements and characterization of the chemical composition of ambient particles sampled in urban/suburban sites showed that IVOC $n$-alkanes were more abundant in the particle-phase in winter than in summer (Kadowaki, 1994; Bi et al., 2003; Guo et al., 2009). Estimation of the hexadecane partition coefficient $K_{\mathrm{p}}$ determined from Pankow theory (Pankow, 1994) show no significant difference between the summer and the winter campaigns $\left(2.16 \times 10^{-4}\right.$ and $8.61 \times 10^{-4}$, respectively) (see the Supplement S1, for details of the $K_{\mathrm{p}}$ calculations). Changes in the emission sources are more likely the cause of their seasonal variations. Regarding the $\mathrm{C}_{6}-\mathrm{C}_{10} n$-aldehydes, to our knowledge, only Knobloch et al. (1997) and Cecinato et al. (2002) compared the seasonal measurements of all these compounds over an urban area. Both studies observed higher concentrations of $\mathrm{C}_{6}-\mathrm{C}_{10} n$-aldehydes in winter than in summer. Conversely, Dutta et al. (2010) found lower concentrations in winter than in summer for hexanal and nonanal. In our study, $\mathrm{C}_{6}-\mathrm{C}_{10} n$-aldehydes concentrations were higher in summer than in winter, suggesting their predominant secondary origin.

\subsection{Temporal evolution of the particulate and gaseous organic compounds}

PMF analyses performed on the particulate organic matter, measured using a HR-TOF-AMS, was used for the characterization of the particulate organic carbon at the SIRTA site (Freutel et al., 2013a). Two PMF components were determined: hydrocarbon-like organic aerosol (HOA) and oxygenated organic aerosol (OOA), respectively representing 40 and $60 \%$ of the organic matter (OM) during the campaign. The first PMF component is associated with primary emis-

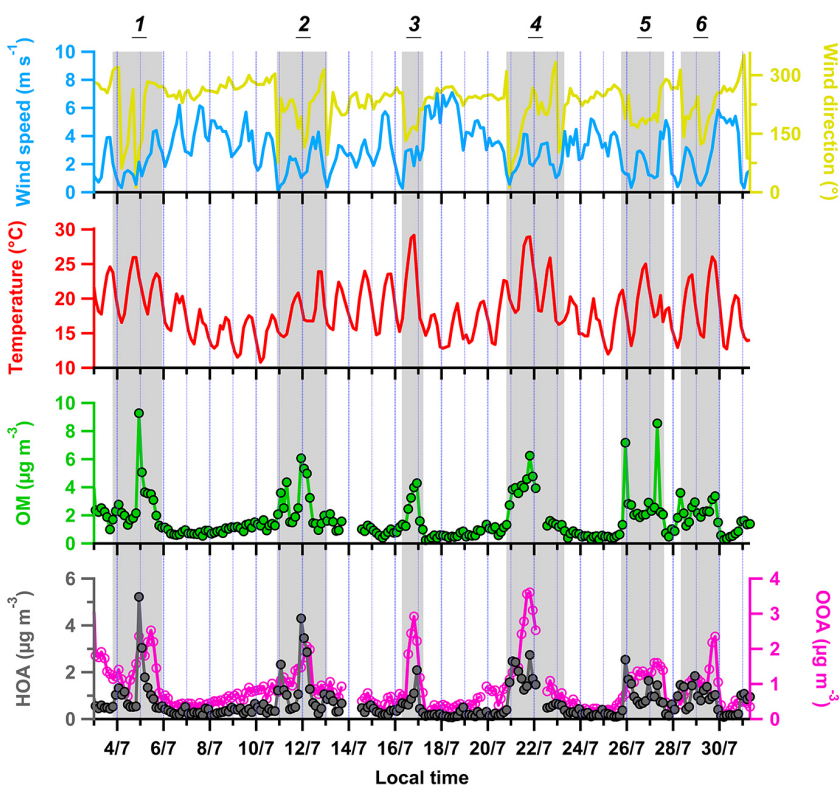

Figure 2. Time series of meteorological parameters (wind speed and direction, temperature), of the organic matter, and of the two PMF factors HOA and OOA in suburban Paris (SIRTA) in summer 2009. The grey-shaded areas highlight the "Atlantic Polluted" wind regimes associated with stagnant conditions and increased OOA.

sions, i.e., directly emitted organic aerosol (Zhang et al., 2005; Aiken et al., 2010; Hodzic et al., 2010). Here, HOA is assumed to represent the total primary organic aerosol, including aerosol emitted from traffic and cooking activities (Freutel et al., 2013a). Further PMF analyses (Crippa et al., 2013b) and single particle analysis (Freutel et al., 2013b) have actually separated the HOA component into the two different components HOA-traffic and cooking organic aerosol (COA). As for OOA, it represents more aged organic aerosol, and therefore is thought to be mainly representative of secondary organic aerosol. The OOA component has also been separated into two different factors based on the PMF analyses of Crippa et al. (2013b): semi-volatile OOA (SV-OOA) and low-volatile OOA (LV-OOA). SV-OOA is considered to be the freshest SOA, i.e., freshly formed, contrary to LVOOA (Jimenez et al., 2009). During the MEGAPOLI summer experiment, SV-OOA and LV-OOA represent on average 56 and $44 \%$ of OOA, respectively. The temporal evolution of the OM and of HOA and OOA PMF components at SIRTA is illustrated in Fig. 2. In addition, this figure depicts some meteorological parameters (wind speed and direction, temperature). Time series of a tracer of primary combustion sources (CO), anthropogenic and biogenic organic SOA precursors (toluene, tetradecane, pentadecane, $\alpha$-pinene and isoprene), and of oxygenated VOCs (nonanal and acetaldehyde), which are known to have secondary sources, are presented in Fig. 3.

Cloudy conditions characterized the summertime campaign: between 3 and 31 July, only a few sunny 


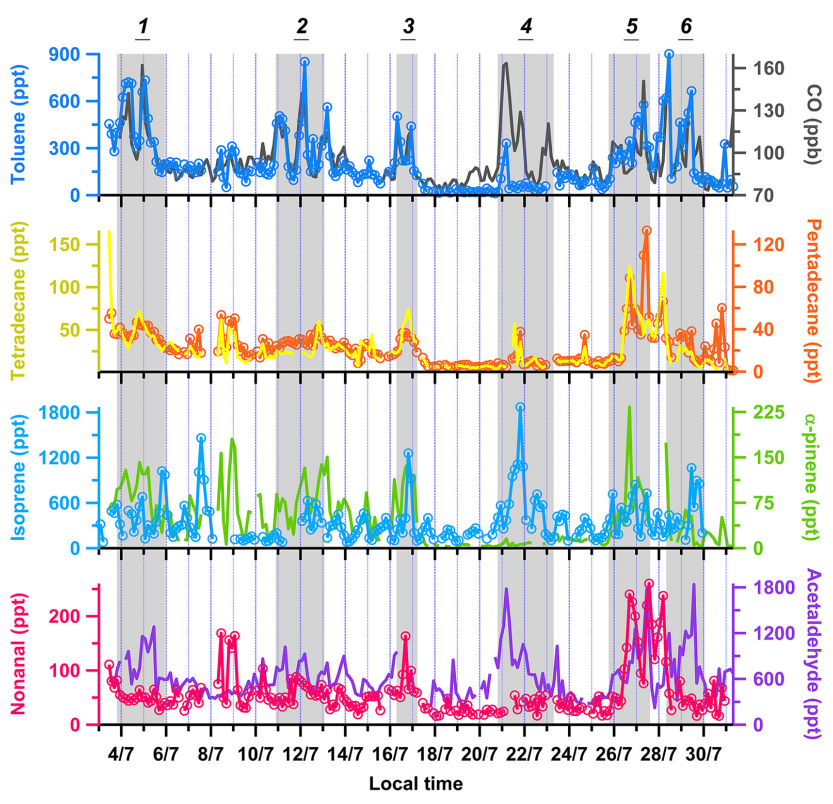

Figure 3. Summertime time series of carbon monoxide, toluene, tetradecane, pentadecane, isoprene, $\alpha$-pinene, nonanal and acetaldehyde. The grey-shaded areas highlight the "Atlantic Polluted" wind regimes associated with stagnant conditions and increased OOA.

days were encountered and the average temperature was $18.3( \pm 3.8)^{\circ} \mathrm{C}$. Southwesterly to westerly winds $\left(215-285^{\circ}\right)$ were dominant. They were associated with the highest wind speed $\left(0.3 \mathrm{~m} \mathrm{~s}^{-1}\right.$ to $\left.7.1 \mathrm{~m} \mathrm{~s}^{-1}\right)$ and the lowest temperature: the average wind speed was $3.7( \pm 1.5) \mathrm{m} \mathrm{s}^{-1}$ associated with an average temperature of $16.8( \pm 3.0)^{\circ} \mathrm{C}$ (Fig. 2). Some periods under influence of southeasterly to southwesterly winds were also encountered. They were characterized by the lowest wind speed $\left(2.1 \mathrm{~m} \mathrm{~s}^{-1}\right.$ on average, ranging from $0.1 \mathrm{~m} \mathrm{~s}^{-1}$ to $5.9 \mathrm{~m} \mathrm{~s}^{-1}$ ) and the highest temperature (from $13.2^{\circ} \mathrm{C}$ to $29.2^{\circ} \mathrm{C}$, with an average value of $20.3^{\circ} \mathrm{C}$ ). This last type of air mass is distinguished in Figs. 2 and 3 by a grey-shaded area. These events under southeasterly/southwesterly influence, lasting $24 \mathrm{~h}$ up to $68 \mathrm{~h}$, are also numbered from 1 to 6 in the following section.

Figure 2 indicates that $3 \mathrm{~h}$ averaged OM mass concentrations ranged from 0.2 to $9.3 \mu \mathrm{g} \mathrm{m}^{-3}$; about $33 \%$ of the data were above the average value of $1.66 \mu \mathrm{g} \mathrm{m}^{-3}$. Like the gaseous compounds, the mass concentration of particulate organic matter is lower than in other megacities: concentrations of organic matter $\left(\mathrm{PM}_{1}\right)$ could reach up to $80 \mu \mathrm{g} \mathrm{m}^{-3}$ in March 2009 in Mexico City (Mexico) (Aiken et al., 2009) and $60 \mu \mathrm{g} \mathrm{m}^{-3}$ in summer 2008 in Beijing (China) (Zhang et al., 2011), respectively, and never less than $10 \mu \mathrm{g} \mathrm{m}^{-3}$. Moreover, in Europe, OM mass concentrations $\left(\mathrm{PM}_{1}\right)$ as low as those observed at SIRTA have been measured at the Jungfraujoch remote site (Switzerland), where summertime concentrations (August 2005) were ranging from about 0.5 to $3.5 \mathrm{\mu g} \mathrm{m}^{-3}$ (Cozic et al., 2008).
As shown by Freutel et al. (2013a), OM showed the lowest levels under a westerly wind regime, with an average mass concentration of $0.9 \mathrm{\mu g} \mathrm{m}^{-3}$. Under stagnant conditions, i.e., during events 1 to 6 , OM mass concentrations clearly increased, as well as the HOA and OOA mass concentrations. An increase in the concentrations was also observed for the VOCs during these periods (Fig. 3), but it appeared to be variable from one event to another, from one gaseous compound to another. Indeed, during event 3 , all the VOCs showed a notable increase in their concentrations, regardless of their emission sources. For the primary anthropogenic VOCs, such as toluene, the biogenic VOCs, like isoprene or $\alpha$-pinene, and for acetaldehyde and other oxygenated VOCs, mean concentrations are about 1.5 times higher than the mean concentrations measured during the previous period influenced by westerly winds (13-16 July). An increase in the VOC concentrations was also observed during event 4 . But, among all the SOA precursors, isoprene is the only one exhibiting a significant enhancement during the entire event; the other compounds, including primary anthropogenic I / VOCs, presented a sharp and short increase of their concentrations on 21 July. Remarkably, the increase in the isoprene concentrations was accompanied by a notable increase in the level of $\mathrm{CO}$. $\mathrm{CO}$ is one of the primary anthropogenic emissions tracers, but it can also result from the photo-oxidation of VOCs, including those of biogenic origin (Gros et al., 2002; Kanakidou et al., 2005; de Gouw et al., 2008). Here, CO shows two increases on 21 July. The first increase occurs during morning hours with little dispersion, very low wind speed, with varying wind direction. Since $\mathrm{CO}$ correlates with toluene during this first increase, $\mathrm{CO}$ is predominantly of primary origin. The second increase is observed for the evening hours and is much more pronounced than those observed for the other primary anthropogenic VOCs. Hence, during event 4, $\mathrm{CO}$ might be of both primary and secondary origin. Besides, since it exhibits a substantial atmospheric lifetime of about a month (Parrish et al., 1998), long-range transport of CO cannot be discarded either. These assumptions are supported by the evening rise in the concentration of light OVOCs, such as acetaldehyde, propanal or MEK (not shown in Fig. 3) and, as it can be seen in Fig. 2, of the oxygenated PMF component of OM, OOA, or of ozone (not shown here) during the same event (end of 21 July).

Finally, the evolution of the VOCs is consistent with the air mass classification of Freutel et al. for the MEGAPOLI campaign period, which was carried out using the FLEXPART simulations (Stohl et al., 2005; Freutel et al., 2013a). Hence, for consistency purposes, the same terms qualifying the air masses, "Atlantic Clean" for plumes with high wind speed and low temperature and "Atlantic Polluted" when air masses are characterized by low wind speed and high temperature, will be used in the following section.

The different particulate and gaseous compounds appear to be strongly impacted by the origin of the air masses arriving at SIRTA during the MEGAPOLI summertime campaigns. 
Table 4. Toluene and $i$-pentane mean concentrations in different cities worldwide.

\begin{tabular}{|c|c|c|c|c|c|}
\hline Location & Period & Site & $\begin{array}{l}\text { Toluene } \\
(\mathrm{ppb})\end{array}$ & $\begin{array}{l}i \text {-Pentane } \\
(\mathrm{ppb})\end{array}$ & Reference \\
\hline Beijing (China) & Sum. 2006 & urban & 19.44 & 17.70 & Duan et al. (2008) \\
\hline Karachi (Pakistan) & Win. 1998 & urban & 7.10 & 12.10 & Barletta et al. (2002) \\
\hline \multirow[t]{2}{*}{ Tokyo (Japan) } & Sum. 2007 & urban & 2.14 & 4.21 & Yoshino et al. (2012) \\
\hline & Win. 2007 & & 10.10 & 2.87 & \\
\hline \multirow{2}{*}{ Mexico City (Mexico) } & February 2002 & urban & 13.45 & 17.02 & Velasco et al. (2007) \\
\hline & and April-May 2003 & rural & 1.89 & 5.82 & \\
\hline $\begin{array}{l}\text { Pasadena (suburb of } \\
\text { Los Angeles, USA) }\end{array}$ & May-June 2010 & suburban & 0.58 & 1.56 & CalNex framework \\
\hline London & October 2006 & urban & 1.85 & $\mathrm{~nm}$ & Langford et al. (2010) \\
\hline (United Kingdom) & 2008 & urban, K. & 1.00 & $\mathrm{~nm}$ & $\begin{array}{l}\text { von Schneidemesser } \\
\text { et al. }(2010)\end{array}$ \\
\hline \multirow[t]{2}{*}{ Zürich (Switzerland) } & Win. 2005/2006 & urban, B. & 1.25 & $\mathrm{~nm}$ & Legreid et al. (2007) \\
\hline & Sum. 2005 & & 1.43 & $\mathrm{~nm}$ & \\
\hline \multirow[t]{2}{*}{ Paris (France) } & Sum. 2009 & urban, B. & 0.73 & 0.73 & MEGAPOLI framework \\
\hline & Win. 2010 & (LHVP) & 0.79 & 0.77 & \\
\hline Dunkerque (France) & 2002-2003 & urban, I. & 1.06 & 0.94 & Badol et al. (2008) \\
\hline Donon (France) & 1997-2006 & rural & 0.16 & 0.21 & Sauvage et al. (2009) \\
\hline Peyrusse-Vieille (France) & 2000-2006 & rural & 0.11 & 0.14 & Sauvage et al. (2009) \\
\hline Tardière (France) & 2002-2006 & rural & 0.27 & 0.21 & Sauvage et al. (2009) \\
\hline \multirow{2}{*}{ Paris (France) } & Sum. 2009 & suburban & 0.20 & 0.33 & This work \\
\hline & Win. 2010 & (SIRTA) & 0.32 & 0.42 & \\
\hline
\end{tabular}

Sum.: summer; Win.: winter; K.: kerbside; B.: background; I.: industrial; nm: not measured.

The pollutant concentrations were low or high as the air mass was characterized by either high or low wind speeds.

\subsection{Concentration levels of VOCs: Paris vs. other areas}

Table 4 compiles mean concentrations of toluene and $i$ pentane, two markers of vehicular exhaust and evaporation emission sources, measured at different locations, including megacities, European urban and suburban areas, and different areas in France. As VOC emissions are rapidly decreasing (Warneke et al., 2012), only observations performed within the last 15 years have been reported in Table 4. Mean concentrations of these VOCs observed at LHVP are also reported in Table 4. SIRTA exhibits the lowest VOC mean concentrations among all these data sets. Toluene mean concentrations in other megacities range from 0.58 to $19.44 \mathrm{ppb}$ : the highest value, measured in summer at an urban site of Beijing (Duan et al., 2008), is a hundred times as high as the summertime toluene mean concentration at SIRTA $(0.20 \mathrm{ppb})$. Higher $i$-pentane levels in other megacities are also observed. In winter, for instance, the $i$-pentane mean concentration at SIRTA $(0.42 \mathrm{ppb})$ is 7 times lower than the minimum mean concentration which was measured in Tokyo (2.87 ppb) (Yoshino et al., 2012). At the suburban site of Paris, the only European megacity with more than 10 million inhabitants listed by the United Nations (United Nations, 2012), the concentrations of these two VOCs remain lower than at other urban/suburban sites in Europe (Legreid et al., 2007; Langford et al., 2010; von Schneidemesser et al., 2010). Even the French urban/urban background areas, including LHVP, have systematically higher VOC mean concentrations than SIRTA, by a factor of up to 15 (Badol et al., 2008; Gros et al., 2011). Finally, the mean concentrations of anthropogenic VOCs (aromatic and alkanes) at SIRTA are as low as those measured at French remote sites (Sauvage et al., 2009) from the EMEP network (European Monitoring and Evaluation Programme). The predominance of oceanic air masses with the highest wind speed arriving at SIRTA, both "Atlantic Clean" or "Atlantic Polluted", favors the dispersion of pollutants in the Paris region (Sect. 3.2).

\section{Anthropogenic emissions of gaseous organic carbon present over suburban Paris}

\subsection{Method}

The analysis of the correlations between pairs of trace gases is a first step towards the identification of the different processes governing the evolution of the compounds, including the emissions, while the effect of dilution is minimized (Roberts et al., 1984). The method relies on the hypothesis of absent or only little chemical loss processes of the compounds. Information on the emission sources is given by the quality of the linear regression fit $\left(R^{2}\right)$ between VOC 

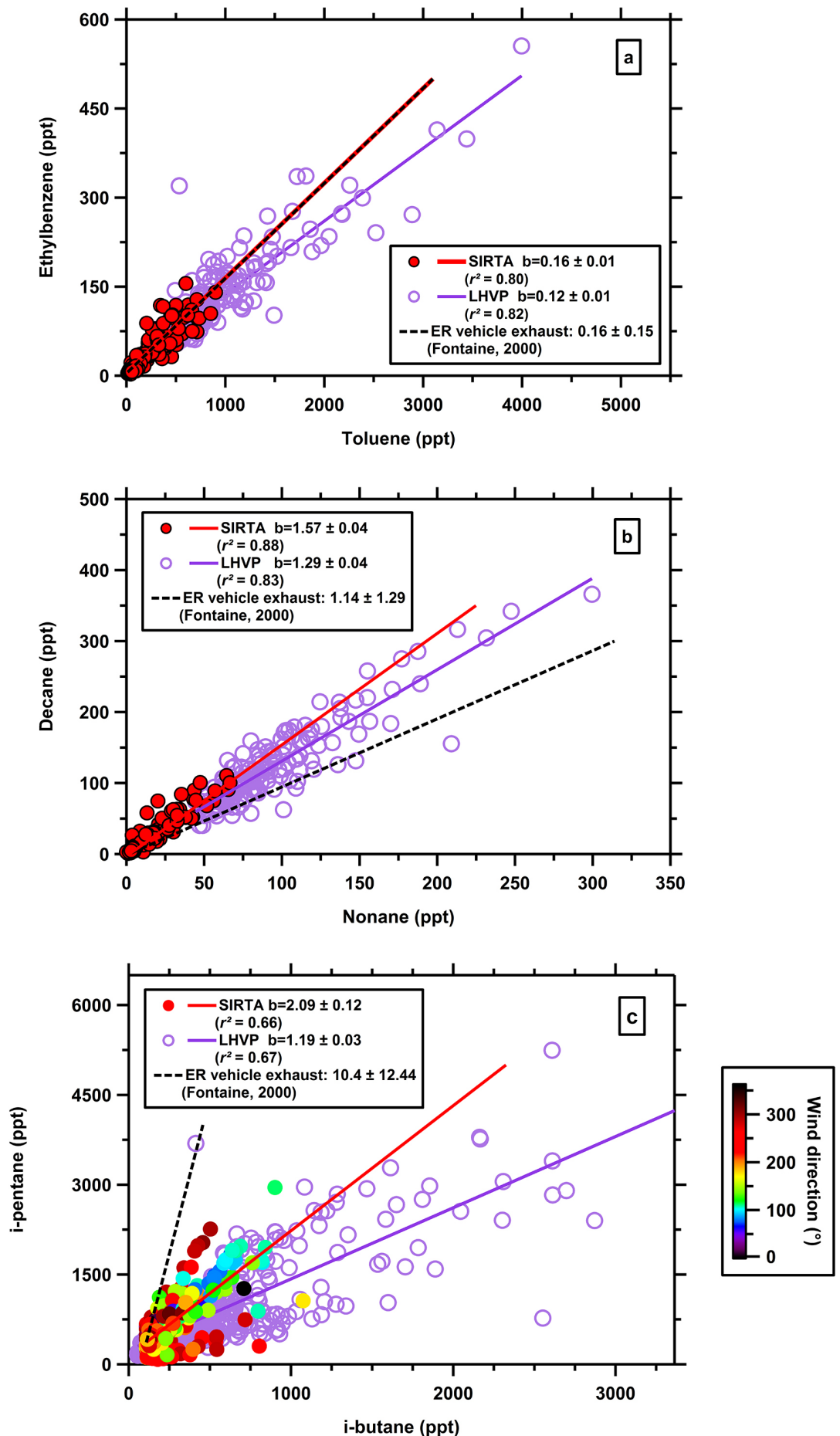

Figure 4. Scatterplots of ethylbenzene versus toluene (a), decane versus nonane (b) and $i$-pentane versus $i$-butane (c) in suburban (SIRTA) and urban (LHVP) Paris in summer. The fit of correlation of $i$-pentane versus $i$-butane at SIRTA (Fig. 5c) does not take into account the upper and lower part of the envelope; SIRTA data are color-coded by the wind direction.

pairs with similar atmospheric lifetime and the value of the slope of the linear regression fit. On the one hand, common sources are highlighted by a tight correlation $\left(R^{2}\right.$ value close to 1) (Parrish et al., 1998). On the other hand, the slope pro- vides the value of the enhancement ratio (Borbon et al., 2003; Warneke et al., 2007). For each pair of VOCs, the enhancement ratio is defined as the enhancement of a VOC relatively to the second one, which is considered as a reference 

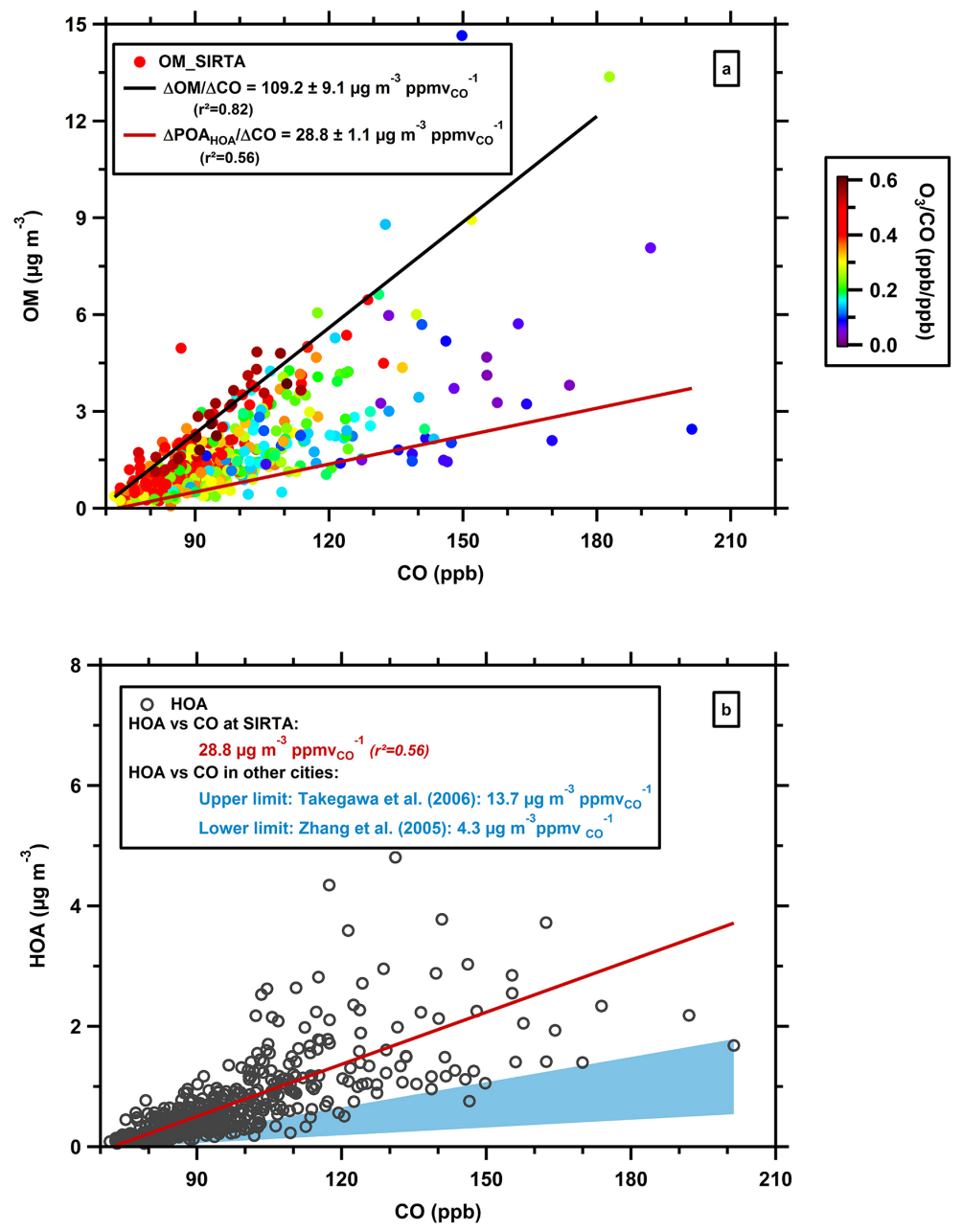

Figure 5. Scatterplots of OM versus CO (a) and scatterplots of HOA versus CO (b) in suburban Paris in summer 2009. OM, CO and HOA were averaged to $1 \mathrm{~h}$.

compound (Hornbrook et al., 2011). Since most NMHCs in the Paris agglomeration are strongly impacted by vehicle exhaust emissions (Borbon et al., 2013), the enhancement ratios obtained at SIRTA are compared with the vehicle exhaust emission ratio derived from emission factors according to the method developed by Borbon et al. (2003). This will allow stating if observed enhancement ratios can be explained by traffic emissions alone. Briefly, emission factors (EF) of VOCs at the exhaust were determined in the late 1990s in France, from vehicles imitating mean urban driving conditions and using different types of fuels: diesel, gasoline with or without catalyst (Fontaine, 2000). The experimental conditions for the determination of the VOCs emission factors by Fontaine (2000) are detailed in the Supplement (Sect. S2); values of VOCs EF can be found in Borbon et al. (2003). In 2009-2010, the fleet of vehicles in Paris was composed of $60 \%$ light-duty diesel vehicles and of $40 \%$ gasoline light-duty vehicles equipped with catalytic convertors (CCFA, 2011). Emission ratios (ER) were then calcu- lated following Eq. (1) defined by Borbon et al. (2003):

$\mathrm{ER}_{\mathrm{VOC}_{1}, \mathrm{VOC}_{2}}=\frac{\sum_{j}\left(\mathrm{EF}_{\mathrm{VOC}_{1}, \mathrm{j}} \times f_{j}\right)}{\sum_{j}\left(\mathrm{EF}_{\mathrm{VOC}_{2}, \mathrm{j}} \times f_{j}\right)}$,

where $\mathrm{ERVOC}_{1}, \mathrm{VOC}_{2}$ is the emission ratio of the given $\mathrm{VOC}_{1}$ with respect to $\mathrm{VOC}_{2}$ (in ppt ppt ${ }^{-1}$ ), $\mathrm{EF}_{\mathrm{VOC}_{i}, j}$ the emission factor of the $\mathrm{VOC}_{i}$ for the engine type $j$ (in $\mathrm{mg} \mathrm{km}^{-1}$ ) and $f_{j}$ the fraction in $\%$ of the urban mileage running by the motor type $j$. The standard deviation of the ratios is determined from the standard deviations of the emission factors. As demonstrated in the Supplement (Sect. S3, Fig. S1), the ER determined from Fontaine's work (2000) are representative of northern mid-latitude urban areas.

\subsection{Spatial variability: evidence of regional influences in suburban Paris}

Summertime correlations of commonly measured VOCs with the same atmospheric lifetimes at SIRTA and LHVP 
are illustrated in Fig. 4. As expected, the comparison of the scatterplots exhibits higher concentrations for anthropogenic VOCs in urban Paris than in suburban Paris as a result of the emission density and dilution. However, the shape and the slope of the scatterplots are fairly consistent between urban and suburban Paris in summer and in winter (not presented here).

Aromatic compounds and heavy alkanes show a narrow distribution with very good correlation $\left(R^{2}>0.80\right.$, Fig. 4 a and b). The emission enhancement ratios in urban and suburban Paris, given by the value of the linear regression fit slopes, agree well within $\pm 2 \%$ and $\pm 18 \%$ for aromatics and alkanes, respectively, regardless of the seasons and within the analytical uncertainties (Fig. 4a and b). The emission enhancement ratios determined during MEGAPOLI are also very close to the emission ratio (reported on Fig. 4) in vehicle exhaust determined from Eq. (1). These observations point to traffic emission as the dominant source of aromatics and alkanes $>\mathrm{C}_{5}$ across the Paris basin in accordance with Borbon et al. (2013).

Scatterplots of light alkanes obtained at SIRTA and LHVP are overlaid (Fig. 4c), indicating that sources of the same composition affect their distribution at each site. These light alkanes are known to be emitted from common sources, i.e., vehicle fuel combustion and evaporation (Monod et al., 2001; So and Wang, 2004; Russo et al., 2010). However, the multi-shape distributions imply that sources with different iso-alkanes composition are driving their distribution in the Paris area. The scatterplot of SIRTA is color-coded as a function of the wind direction. When SIRTA is downwind of the $225-330^{\circ}$ sector, enrichment in either $i$-pentane (upper part of the envelope) or $i$-butane (lower part of the envelope) is observed. Plumes arriving from the northwest at SIRTA flew over the Seine basin. In spring 2007, Gaimoz et al. (2011) also observed enrichment in $i$-butane concentrations in urban Paris when sampling oceanic air masses which had crossed this region. The Seine basin is an important industrialized area including different industries: chemistry, surface treatment and oil and gas production (iREP, 2012). When the upper and lower part of the envelope, which correspond to the data associated with the $225-330^{\circ}$ wind sector, are not taken into account, a good correlation is obtained at SIRTA $\left(R^{2}=0.66\right)$ with a slope of $2.09\left(\mathrm{ppt} \mathrm{ppt}^{-1}\right)$ for the Paris wind sector. Contrary to the aromatic compounds and the heavy alkanes, the enhancement ratio of the light alkanes determined at SIRTA is very different from the vehicle exhaust emission ratio, namely by a factor of 4 to 5 . This difference may indicate either a difference in gasoline composition or emission sources other than vehicular exhaust. This assumption is supported by the low wintertime $i$-pentane $/ i$-butane ratio obtained at SIRTA from the VOCs' scatterplot $(0.70$, $R^{2}=0.65-$ not shown here).

Finally, the analysis of VOC/VOC correlations highlights the similar distribution of anthropogenic VOCs across the Greater Paris region, and so their common sources. This dis- tribution is influenced by emissions from the whole Paris area as well as from the advection of industrial emissions along the Seine River for light alkanes. Thus, the SIRTA site is representative of regional anthropogenic footprint emissions. Similar conclusions were obtained from the observations of the particulate matter: the different organic and inorganic components of the PM1 particles exhibit the same trend at the different MEGAPOLI measuring sites (Crippa et al., 2013a; Freutel et al., 2013a).

\section{Estimation of the contribution of I / VOCs to SOA formation in summer}

Two different approaches can be used to quantify and qualify the contribution of VOC and IVOC precursors to the SOA formation: the integrated approach and the time-resolved approach. This chapter focuses on the description of these two approaches and a discussion of the obtained results.

\subsection{Method}

\subsubsection{Estimation of the SOA from its gaseous precursors: the integrated approach}

The method developed by de Gouw et al. $(2005,2008)$, the so-called integrated approach, is first applied to our data. This approach consists of the apportionment of $\Delta \mathrm{OM} / \Delta \mathrm{CO}$ enhancement into its primary component $(\triangle \mathrm{POA} / \Delta \mathrm{CO})$ and its secondary component $(\triangle \mathrm{SOA} / \Delta \mathrm{CO}) . \Delta \mathrm{OM} / \Delta \mathrm{CO}$ is derived from the scatterplot of OM vs. CO. Experimentally, the $\Delta \mathrm{SOA} / \triangle \mathrm{CO}$ enhancement is the difference between $\Delta \mathrm{OM} / \Delta \mathrm{CO}$ and $\triangle \mathrm{POA} / \Delta \mathrm{CO}$, as illustrated by Eq. (2):

$\left(\frac{\Delta \mathrm{SOA}}{\Delta \mathrm{CO}}\right)_{\text {experimental }}=\left(\frac{\Delta \mathrm{OM}}{\Delta \mathrm{CO}}\right)-\left(\frac{\Delta \mathrm{POA}}{\Delta \mathrm{CO}}\right)$.

In addition, a theoretical $\Delta \mathrm{SOA} / \Delta \mathrm{CO}$ enhancement is derived from the product of the VOC emission ratios to $\mathrm{CO}$ and the SOA yields of these VOCs, as described by Eq. (3):

$\left(\frac{\Delta \mathrm{SOA}}{\Delta \mathrm{CO}}\right)_{\text {theoretical }}=\sum_{i} \mathrm{ER}_{i} \times Y_{\mathrm{SOA}, i}$,

with $\mathrm{ER}_{i}$ and $Y_{\mathrm{SOA}, i}$ the emission ratio and the SOA yield formation of the $\mathrm{VOC}_{i}$, respectively. The comparison of these experimentally and theoretically derived SOA enhancements allows for the quantification of the effective contribution of the measured VOCs to the secondary formation of the aerosol particles. Based on the emission ratio, this approach considers that the amount of emitted I / VOC reacts entirely to form SOA. This approach leads then to an upper limit for the estimation of SOA formation from a gaseous precursor. Since CO is used as a primary anthropogenic tracer, the estimation of the SOA formation can be established by only considering VOCs of primary anthropogenic origin. Here, the measured $n$-alkanes of intermediate volatility, measured at SIRTA, will be included for the first time. 


\subsubsection{Estimation of the SOA from its gaseous precursors: the time-resolved approach}

A second method, the so-called time-resolved approach adapted from Sjostedt et al. (2011), is applied to the data. Like the first approach, the aim of the time-resolved approach is to quantify the contribution of the different anthropogenic SOA precursors. However, unlike the first approach, the chemical atmospheric removal of the SOA precursors is considered, rather than their emission ratio. In this approach, it is assumed that the I/ VOCs are removed from the atmosphere only by reaction with the hydroxyl radical. Their reaction with ozone or the nitrate radical is slow enough (Atkinson and Arey, 2003) to be neglected in SOA formation, even though the SOA yields from their reaction with $\mathrm{NO}_{3}$ can be much higher, as observed for isoprene and the monoterpenes (Fry et al., 2009, 2011).

Thus, in this approach, the I / VOCs are assumed to follow a pseudo first-order kinetic reaction, such as

$-\frac{d\left[\mathrm{VOC}_{i}\right]}{d t}=k_{\mathrm{VOC}_{i}}\left[\mathrm{VOC}_{i}\right][\mathrm{OH}]$,

with $k_{\mathrm{VOC}_{i}}$ the rate constant of $\mathrm{VOC}_{i}$ with the $\mathrm{OH}$ radical $\left(\mathrm{cm}^{3}\right.$ molecule $\left.{ }^{-1} \mathrm{~s}^{-1}\right),[\mathrm{OH}]$ the concentration of the hydroxyl radical (molecule $\mathrm{cm}^{-3}$ ), and $\left[\mathrm{VOC}_{i}\right]$ the concentration of a given VOC. The initial concentration of a given $\mathrm{VOC},\left[\mathrm{VOC}_{i}\right]_{t=0}$, is then retrieved from Eq. (4), such as in Eq. (5):

$\left[\mathrm{VOC}_{i}\right]_{t=0}=\left[\mathrm{VOC}_{i}\right]_{\mathrm{SIRTA}, t} \times\left(e^{k \mathrm{VOC}_{i} \times[\mathrm{OH}] \times \Delta t}\right)$,

where $\left[\mathrm{VOC}_{i}\right]_{\text {SIRTA }, t}$ is the $\mathrm{VOC}_{i}$ concentration measured at SIRTA (ppt) and $\Delta t$ the time elapsed since the emission. The removal of a gaseous compound, $\Delta\left[\mathrm{VOC}_{i}\right]$, is therefore estimated from Eq. (7):

$$
\begin{aligned}
& \Delta\left[\mathrm{VOC}_{i}\right]=\left[\mathrm{VOC}_{i}\right]_{t=0}-\left[\mathrm{VOC}_{i}\right]_{\text {SIRT } A, t} \\
& \Delta\left[\mathrm{VOC}_{i}\right]=\left[\mathrm{VOC}_{i}\right]_{\text {SIRTA }, t} \times\left(e^{\left(k^{\left.\mathrm{VOC}_{i} \times[\mathrm{OH} \times \Delta t]\right)}-1\right) .}\right.
\end{aligned}
$$

Finally, for a given I / VOC, the result obtained in Eq. (7) is multiplied by the SOA yield (Table 3), resulting in the amount of SOA produced by the given I/ VOC at time $t$. The total SOA mass concentration estimated on a temporal basis is obtained by adding the amount of SOA produced by all the VOCs, as expressed by Eq. (8):

$\mathrm{SOA}_{\text {estimated }}=\sum_{i} \Delta \mathrm{VOC}_{i} \times Y_{\mathrm{SOA}, i}$.

\subsubsection{Assumptions in the different approaches}

Both estimations of the SOA amount formed from the oxidation of I / VOCs rely on different assumptions that are discussed in the following section. Additional details on the assumptions can be found in the Supplement (Sect. S4).
1. The SOA yields. The SOA yields used here (provided in Table 3 ) are the most recent ones determined in chamber experiments, and the most relevant to the MEGAPOLI campaign conditions. SOA yields are known to be highly influenced by the experimental conditions in the chamber, especially by the $\mathrm{NO}_{\mathrm{x}}$ concentrations and the organic mass concentrations $\left(C_{\mathrm{OA}}\right)$ (Hildebrandt et al., 2009; Presto et al., 2010; Aumont et al., 2012; Tkacik et al., 2012). At SIRTA, on average, $C_{\mathrm{OA}}=1.8 \mathrm{\mu g} \mathrm{m}^{-3}$ and the $\mathrm{NO}_{\mathrm{x}}$ concentration is $6.9 \pm 4.8 \mathrm{ppb}$. These environmental conditions correspond to low- $C_{\mathrm{OA}}$ and low- $\mathrm{NO}_{\mathrm{x}}$ conditions, regarding chamber experiments. While chamber experiment conditions under which SOA yields are determined are quite variable, they never meet both the low- $\mathrm{NO}_{\mathrm{x}}$ and low- $C_{\mathrm{OA}}$ criteria. SOA yields of the aromatic compounds were either determined at low- $\mathrm{NO}_{\mathrm{x}}$ or high- $\mathrm{NO}_{\mathrm{x}}(\mathrm{Ng}$ et al., 2007a) conditions but always at high $C_{\mathrm{OA}}=40 \mu \mathrm{g} \mathrm{m}^{-3}$ (see the Supplement, Sect. S4 for details). Conversely SOA yields of the volatile and $\mathrm{C}_{13}-\mathrm{C}_{16}$ intermediate volatile $n$-alkanes were determined at high or low $C_{\mathrm{OA}}$ but always under high- $\mathrm{NO}_{\mathrm{x}}$ conditions (Lim and Ziemann, 2009a; Presto et al., 2010). Therefore, the SOA formation will be studied using two sets of SOA yields for the $\mathrm{C}_{12}-\mathrm{C}_{16} n$-alkanes and the aromatics, from the integrated approach only. The first SOA yield values reported in Table 3 are those determined under the most relevant atmospheric conditions for this study, i.e., low $C_{\mathrm{OA}}=2 \mu \mathrm{g} \mathrm{m}^{-3}$ (but high $\mathrm{NO}_{\mathrm{x}}$ ) for the IVOCs and low$\mathrm{NO}_{\mathrm{x}}$ (but high $C_{\mathrm{OA}}=40 \mu \mathrm{g} \mathrm{m}^{-3}$ ) for the aromatics. The second SOA yield values are those obtained from chamber experiments performed under similar $C_{\mathrm{OA}}$ and $\mathrm{NO}_{\mathrm{x}}$ conditions, i.e., high $\mathrm{NO}_{\mathrm{x}}$ and high $C_{\mathrm{OA}}=40 \mu \mathrm{g} \mathrm{m}^{-3}$. The second set of SOA yields will be used to compare the contribution to SOA formation of the $\mathrm{C}_{12}-$ $\mathrm{C}_{16} n$-alkanes against the contribution of the whole VOC set. $\mathrm{C}_{9}-\mathrm{C}_{11} n$-alkanes SOA yields are those determined by Lim and Ziemann (2009a) under high $\mathrm{NO}_{\mathrm{x}}$ and high $C_{\mathrm{OA}}\left(400 \mu \mathrm{g} \mathrm{m}^{-3}<C_{\mathrm{OA}}<1600 \mu \mathrm{g} \mathrm{m}^{-3}\right)$ conditions. High- $\mathrm{NO}_{\mathrm{x}} \mathrm{SOA}$ yields are much more important than low- $\mathrm{NO}_{\mathrm{x}} \mathrm{SOA}$ yields for the $n$-alkanes (Loza et al., 2014). Besides, the higher $C_{\mathrm{OA}}$ is, the higher the SOA yield is (Hildebrandt et al., 2009; Presto et al., 2010; Aumont et al., 2012; Tkacik et al., 2012).

2. The VOC/CO emission ratios. The ER to $\mathrm{CO}$ are the ones determined for the Paris area based on the LHVP ground site and airborne data by Borbon et al. (2013). While the SIRTA site was rarely downwind of the Paris plume, Borbon et al. (2013) and Boynard et al. (2014) showed that VOC/VOC ER were usually consistent between northern mid-latitude urban areas. However, the $\mathrm{C}_{11}-\mathrm{C}_{16}$ alkanes were not measured at LHVP. For this reason, their emission ratios have been estimated from the ER determined at vehicle exhaust by Fontaine 
(2000), as previous studies state that volatile alkanes and alkanes of intermediate volatility are mainly emitted from vehicle exhaust (Fraser et al., 1998; Schauer et al., 1999a). These ratios are not expected to have changed between 2000 and 2009 (see Fig. S2 in the Supplement).

3. $[\mathrm{OH}] \times \Delta t$. The product of $[\mathrm{OH}]$ and $\Delta t$ is derived from the photochemical age. The photochemical age is an indicator of the photochemical processing induced by the hydroxyl radical, and so of the chemistry affecting the VOCs, from their emission to their measurement at the receptor site. It is based on the ratio of two VOCs, usually aromatic compounds (Nelson and Quigley, 1983; Roberts et al., 1984; Parrish et al., 1998; Monod et al., 2001; Warneke et al., 2007). m,p-Xylenes and ethylbenzene are the two VOCs used here in the calculation of the photochemical age. Besides, the photochemical age takes into account the ratios of VOC concentrations at the emission site and at the receptor site. Here, the LHVP VOCs concentration ratio is considered at $t=0$, since ratios at LHVP are representative of urban emission ratios (Borbon et al., 2013). Finally, the product of $[\mathrm{OH}]$ and $\Delta t$ is calculated following Eq. (9):

$$
\begin{aligned}
& {[\mathrm{OH}] \times \Delta t=\frac{1}{\left(k_{\mathrm{m}, \mathrm{p} \text {-xylenes }}-k_{\text {ethylbenzene }}\right)}} \\
& \times\left[\left.\ln \frac{[\mathrm{m}, \mathrm{p} \text {-xylenes }]}{[\text { ethylbenzene }]}\right|_{\text {LHVP, } t=0}\right. \\
& \left.-\left.\ln \frac{[\mathrm{m}, \mathrm{p} \text {-xylenes }]}{[\text { ethylbenzene }]}\right|_{\text {SIRTA }, t}\right],
\end{aligned}
$$

with $k_{\mathrm{m}, \mathrm{p}-\mathrm{xylene}}$ and $k_{\text {ethylbenzene }}$ the rate constants with $\mathrm{OH}$, as reported in Table 3, and $\mid[\mathrm{m}, \mathrm{p}$-xylenes $] /$ [ethylbenzene $]\left.\right|_{\text {LHVP, } t=0}$ the m,pxylenes/ethylbenzene ratio at time $t=0$, i.e., the emission ratio of $\mathrm{m}, \mathrm{p}$-xylenes to ethylbenzene. In this calculation, $k_{\mathrm{m}, \mathrm{p}-\mathrm{xylene}}$ is taken equal to $k_{\mathrm{m} \text {-xylene }}$, the $\mathrm{m}$-xylene/p-xylene ratio is equal to $2.23\left(\right.$ pptv pptv $^{-1}$ ) in urban areas (Monod et al., 2001).

4. The use of an inert tracer for the normalization. Equation (7) coupled to Eq. (9) considers that the compounds are in a constant volume from the emission source until the receptor, neglecting the dilution. To overcome the effect of dilution, de Gouw et al. (2009) had determined the VOC removal from the temporal evolution of the VOC/CO ratio; the removal relies then on the VOC emission ratio instead of a calculated initial concentration. However, here it was not possible to use $\mathrm{CO}$ as an inert tracer due to its levels close to background, estimated to be about $100 \mathrm{ppb}$ at a remote European site (Balzani Lööv et al., 2008) (see Fig. 3). Besides, normalization to one of the $\mathrm{C}_{4}-\mathrm{C}_{5}$ alkanes, which exhibit the longest atmospheric lifetime among all the VOCs measured during the MEGAPOLI summertime experiment (Table 3), was not feasible since they are emitted from diverse sources (Sect. 4.2). Finally, no normalization was applied at all.

Other simplifications are considered for the timeresolved approach: it is assumed that (i) no I / VOC is added to the plume between the emission site and the sampling site, which is described as an obvious simplification by de Gouw et al. (2009), (ii) SOA is produced instantaneously from the VOC reaction and (iii) is not subject to loss by deposition (Sjostedt et al., 2011).

5. The biogenic VOC precursors. Neither of the SOA estimation approaches included any biogenic SOA precursors. The integrated approach uses $\mathrm{CO}$ as an inert tracer, while the time-resolved approach relies on the ratio of anthropogenic VOCs to determine the photochemical age. Since biogenic VOCs have different emission sources than $\mathrm{CO}$ or anthropogenic VOCs, they cannot be taken into account in the SOA estimation in the integrated approach. Since they are very reactive, they cannot be estimated with the time varying approach (they would be completely lost). However, biogenic VOCs are known to be important SOA precursors (Lee et al., 2006a; Ng et al., 2007b). Their exclusion from the two approaches implies an expected underestimation of the theoretical SOA formation and will be discussed in Sect. 5.2.3.

6. Gas-phase chemistry vs. heterogeneous chemistry. Typically estimations only consider SOA formation under dry conditions. Nevertheless, aqueous-phase production is another possible pathway to SOA formation (Carlton et al., 2008; Ervens et al., 2011). Carlton et al. (2008) improved the agreement between observations and predictions of total mass concentrations and its variability, especially of organic aerosol in the regional air quality model, by taking into account SOA formed in the aqueous phase. Finally, the consideration of only gas-phase SOA formation in this study probably also likely leads to an underestimation of SOA formation.

To conclude, both approaches only consider the contribution of anthropogenic VOC precursors to SOA formation and homogeneous chemistry in the gas phase. As a consequence, one could expect an overall underestimation of SOA formation. Moreover, SOA yields determined in the conditions of chamber experiments are not perfectly representative of the real atmospheric conditions (high $\mathrm{NO}_{\mathrm{x}}$ and/or high $C_{\mathrm{OA}}$ loads). The discussion in Sect. 5 will be focused on the role of anthropogenic VOC classes to SOA formation and in particular the importance of IVOC compared to traditional aromatic precursors, when taking into account the most adapted SOA yields. 


\subsection{Results and discussions}

\subsubsection{Estimation of SOA from its gaseous precursors: the integrated approach}

The first step in the integrated approach consists of determining the value of the $\Delta \mathrm{OM} / \Delta \mathrm{CO}$ enhancement ratio. Figure 5a shows the scatterplot of OM to $\mathrm{CO}$ averaged to $1 \mathrm{~h}$ at SIRTA. The data points have been color-coded by the $\mathrm{O}_{3} / \mathrm{CO}$ ratio, which is used here as a proxy of photochemical processing. This indicator considers $\mathrm{CO}$ as purely of primary origin. In our case, as discussed in Sect. 3.3, secondary CO might have been sampled at SIRTA on 21 July. However, this represents only $3 \%$ of the summertime data set, allowing the $\mathrm{O}_{3} / \mathrm{CO}$ ratio to be used as a proxy of the photochemical processing. Hence, fresh air masses with low photochemical processing show the lowest level of ozone and the highest level of $\mathrm{CO}$ : the ratio $\mathrm{O}_{3} / \mathrm{CO}$ tends to zero. Processed air masses show the highest level of ozone and the lowest level of $\mathrm{CO}$ : the ratio $\mathrm{O}_{3} / \mathrm{CO}$ increases. The data with a higher photochemical processing tend to follow a steeper line (highest $\mathrm{O}_{3} / \mathrm{CO}$ ratio) than the points with a lower photochemical processing (lowest $\mathrm{O}_{3} / \mathrm{CO}$ ratio). Part of the $\mathrm{OM}$ scatter can therefore be explained by the secondary formation of organic matter. As a consequence, the value of the $\Delta \mathrm{OM} / \triangle \mathrm{CO}$ enhancement ratio is determined from the fit of the correlation of data with an $\mathrm{O}_{3} / \mathrm{CO}$ ratio higher than $0.5\left(\mathrm{ppb} \mathrm{ppb}^{-1}\right)$, which corresponds to the upper limit of the scatterplot envelope, implying that a maximum OM enhancement is considered here. The $\Delta \mathrm{OM} / \Delta \mathrm{CO}$ enhancement observed at SIRTA in summer was

$$
\left(\frac{\Delta \mathrm{OM}}{\Delta \mathrm{CO}}\right)=(109.2 \pm 9.1) \mu \mathrm{g} \mathrm{m}^{-3} \mathrm{ppmv}^{-1} \text {. }
$$

The POA emission ratio has been determined by plotting the HOA PMF component determined at SIRTA (Freutel et al., 2013a) versus CO, which is illustrated in Fig. 5b, both HOA and $\mathrm{CO}$ were averaged to 1 hour. At SIRTA, the fit of the correlation was

$$
\left(\frac{\Delta \mathrm{POA}_{\mathrm{HOA}}}{\Delta \mathrm{CO}}\right)=(28.8 \pm 1.1) \mu \mathrm{gm}^{-3} \mathrm{ppmv}^{-1} .
$$

This value is consistent with the line describing the lower limit of the scatterplot envelope in Fig. 5a. However, this POA emission ratio is higher than all the values reported in the literature so far (Fig. 5b). The value obtained at SIRTA is at least two times higher than the ones observed in the American urban areas of Pittsburgh (Zhang et al., 2005), New England (de Gouw et al., 2008) and Mexico City (Aiken et al., 2009). The important use of diesel by light-duty cars in Europe, and more particularly in France, might explain the higher POA emission ratio determined at SIRTA: not only do diesel-fueled vehicles emit less $\mathrm{CO}$ than gasoline-fueled vehicles (Allan et al., 2010; Gentner et al., 2013), but the

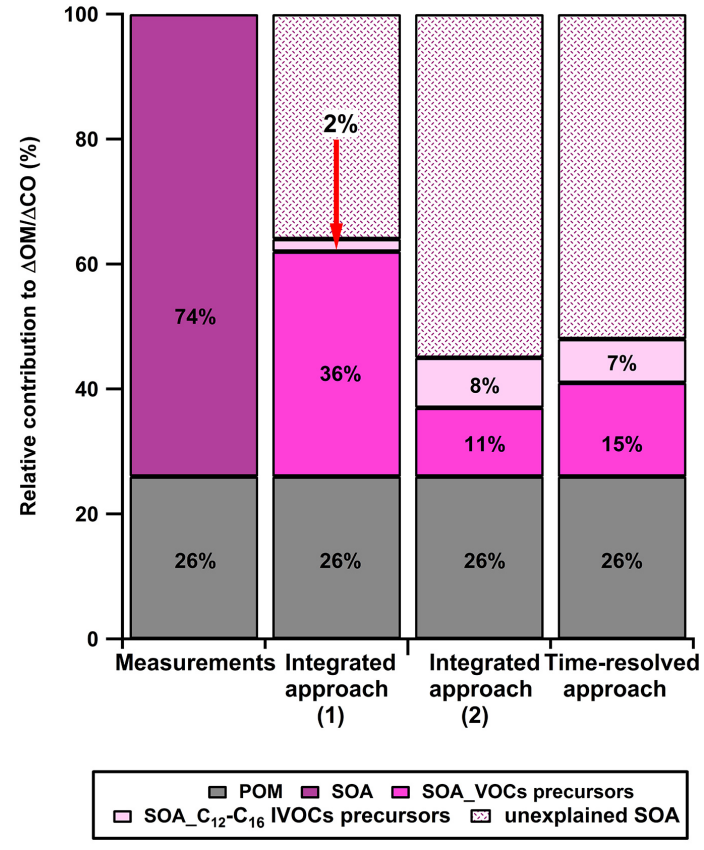

Figure 6. Comparison between the relative contribution to $\Delta \mathrm{OM} / \triangle \mathrm{CO}$ of measured SOA and SOA estimated from VOCs (SOA_VOCs precursors) and from the $\mathrm{C}_{12}-\mathrm{C}_{16}$ IVOCs (SOA_IVOCs precursors), from integrated and time-resolved approaches in suburban Paris during summer 2009. SOA yields of atmospheric relevancy were used in the integrated approach (1); SOA yields determined under high $\mathrm{NO}_{\mathrm{x}}$ and high $C_{\mathrm{OA}}$ were used in the integrated approach (2). Numbers in the bars correspond to the relative mass concentration (\%) explained by each type of organic matter.

POA emission factor is 14 times more important from dieselfueled vehicles (heavy-duty) than from gasoline-fueled cars (light-duty) (Dallmann et al., 2013). Also, some contributions from primary sources other than traffic to the HOA factor (e.g., cooking) could also potentially play a role (Crippa et al., 2013b; Freutel et al., 2013a, b).

Finally, the experimental value of the secondary OA increase is determined from Eq. (2) and found to be equal to

$$
\begin{aligned}
& \left(\frac{\Delta \mathrm{SOA}}{\Delta \mathrm{CO}}\right)_{\text {measured }}=(109.2-28.8) \mu \mathrm{g} \mathrm{m}^{-3} \mathrm{ppmv}^{-1} \\
& \left(\frac{\Delta \mathrm{SOA}}{\Delta \mathrm{CO}}\right)_{\text {measured }}=80.4 \mu \mathrm{g} \mathrm{m}^{-3} \mathrm{ppmv}^{-1} .
\end{aligned}
$$

The theoretical SOA to CO enhancement is then obtained by summing the product of the SOA yield formation with the emission ratio of the individual VOCs relative to $\mathrm{CO}$, including aromatic compounds, $\mathrm{C}_{4}-\mathrm{C}_{6}$ and $\mathrm{C}_{9}-\mathrm{C}_{11}$ alkanes and the $\mathrm{C}_{12}-\mathrm{C}_{16}$ alkanes of intermediate volatility (Eq. 3 ).

Illustrating the distribution of OM between its primary and its secondary components, Fig. 6 compares measured SOA and SOA estimated from I / VOCs measured at SIRTA during the MEGAPOLI summer campaign using SOA yields 


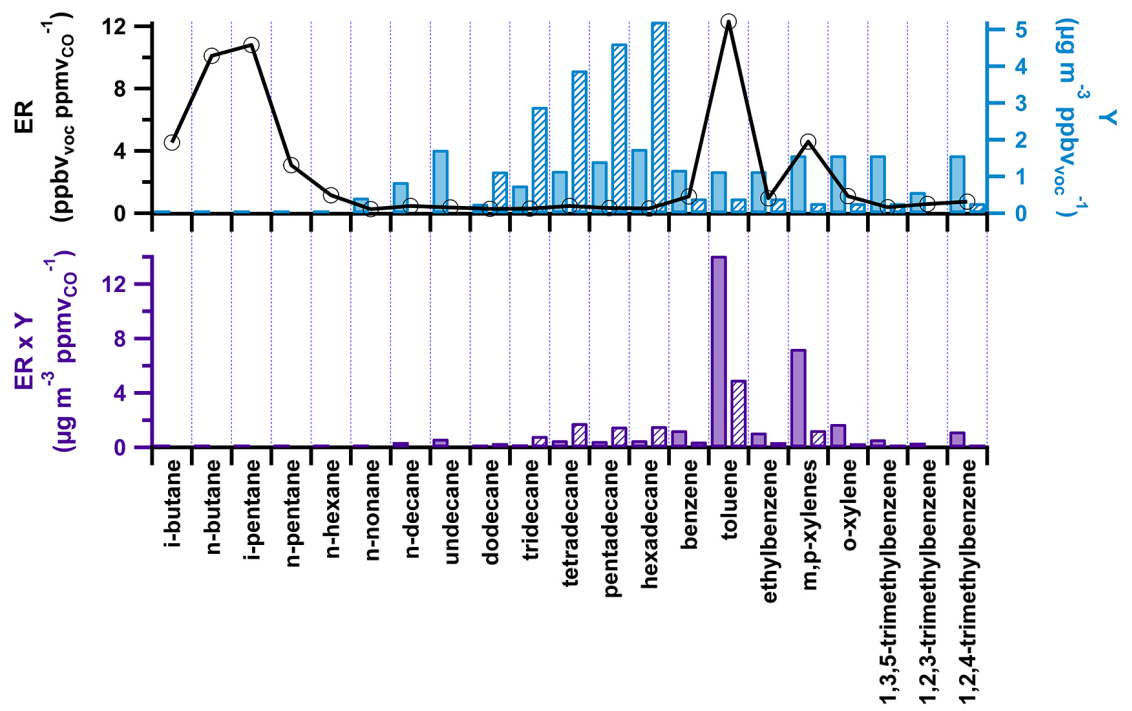

Figure 7. Emission ratios (ER) determined during the MEGAPOLI summer campaign and SOA yields (Y) of relevant VOC precursors (upper panel); products of emission ratios and SOA yields (lower panel). For the $\mathrm{C}_{12}-\mathrm{C}_{16}$ IVOCs, the solid bars represent $\mathrm{Y}$ (and ER $\times \mathrm{Y}$ ) determined under the most relevant atmospheric conditions regarding the environmental conditions encountered at SIRTA during the MEGAPOLI summer campaign; the dashed bars represent $\mathrm{Y}$ (and $\mathrm{ER} \times \mathrm{Y})$ determined under similar conditions $\left(C_{\mathrm{OA}}=40 \mu \mathrm{g} \mathrm{m}^{-3}\right.$ and high $\left.\mathrm{NO}_{\mathrm{x}}\right)$.

determined under atmospheric-relevant conditions, i.e., low $C_{\mathrm{OA}}$ and high $\mathrm{NO}_{\mathrm{x}}$ for the measured IVOCs and high $C_{\mathrm{OA}}$ and low $\mathrm{NO}_{\mathrm{x}}$ for the aromatics, and under similar atmospheric conditions, i.e., high $C_{\mathrm{OA}}$ and high $\mathrm{NO}_{\mathrm{x}}$. As shown in Fig. 6, from SOA of atmospheric relevancy, the measured I / VOC precursors explain $38 \%$ of the SOA measured at SIRTA: $28.6 \mu \mathrm{g} \mathrm{m}^{-3} \mathrm{ppmv}^{-1}-$ i.e. $36 \%$ of the measured SOA were explained by the traditional VOC precursors, which is consistent with the results of de Gouw et al. (2008) (who reported $37 \%$ ), and $1.8 \mu \mathrm{g} \mathrm{m}^{-3} \mathrm{ppmv}^{-1}$, i.e., $2 \%$ of the measured SOA, by the $\mathrm{C}_{12}-\mathrm{C}_{16} n$-alkane IVOCs. At SOA yields determined under similar environmental conditions $\left(C_{\mathrm{OA}}=40 \mu \mathrm{g} \mathrm{m}^{-3}\right.$, high $\left.\mathrm{NO}_{\mathrm{x}}\right)$, the measured IVOCs explain $6.1 \mu \mathrm{g} \mathrm{m}^{-3} \mathrm{ppmv}^{-1}$ - i.e. $8 \%$ of the measured SOA, while the volatile compounds contribution to SOA formation drops to $11 \%\left(9.1 \mu \mathrm{g} \mathrm{m}^{-3} \mathrm{ppmv}^{-1}\right)$. Figure 7 reports the emission ratio of the gaseous compounds, their particulate yield(s) (determined under the most adapted environmental conditions regarding the conditions at SIRTA and under similar conditions for the IVOCs and the aromatic compounds), and the product of the two. It can be seen that light alkanes, which have the highest emissions, exhibit low to no SOA formation potential. Among all the VOCs, toluene and, to a lesser extent $\mathrm{m}, \mathrm{p}$-xylenes, exhibit high emission ratios, and the most important contribution to the SOA formation. For SOA yields representative of the atmospheric conditions encountered at SIRTA during the summertime MEGAPOLI campaign, aromatic compounds dominate SOA formation. The $\mathrm{C}_{13}-\mathrm{C}_{16} n$ alkanes exhibit SOA yields as high as some aromatics, but their contribution to SOA formation remains low because of their ER, which is a factor of 40 lower than the aromatics ER.
When considering the SOA determined under similar conditions, the IVOCs particulate yields are high enough to counterbalance their low emission ratios. Besides, the aromatic compounds that SOA yields are lower under high- $\mathrm{NO}_{\mathrm{x}}$ conditions, reducing then their contribution to SOA formation. Under similar conditions, the $n$-alkane IVOCs up to $\mathrm{C}_{16}$ appear to contribute significantly to the SOA formation as much as the commonly measured aromatic compounds (benzene, ethylbenzene and o-xylene).

\subsubsection{Estimation of SOA from its gaseous precursors: the time-resolved approach}

The temporal evolution of the estimated SOA from the timeresolved approach (Eqs. 7, 8 and 9), by using VOCs or $\mathrm{I} /$ VOCs (sum of VOCs and $\mathrm{C}_{12}-\mathrm{C}_{16} n$-alkane IVOCs), is illustrated in Fig. 8 with the temporal evolution of the OOA PMF component. For this approach, SOA has been estimated by using only SOA yields of atmospheric relevance. Weak consistency is observed between the temporal evolution of measured SOA and the one estimated only from the traditional VOCs, explaining $15 \%$ of SOA. The SOA events are barely noticeable in the latter case: the estimated SOA is as high between 13 and 16 July and between 16 and 17 July, while this latter period is an SOA event according to the measurements. When the IVOCs are taken into account, the estimation of SOA mass is improved: they explain $7 \%$ of the measured SOA. However, the consistency between measured and estimated SOA remains weak when the IVOCs are taken into account, especially when SIRTA receives "Atlantic Polluted" air masses. Event 4 is characterized by an important underestimation of the SOA mass concentration from both 


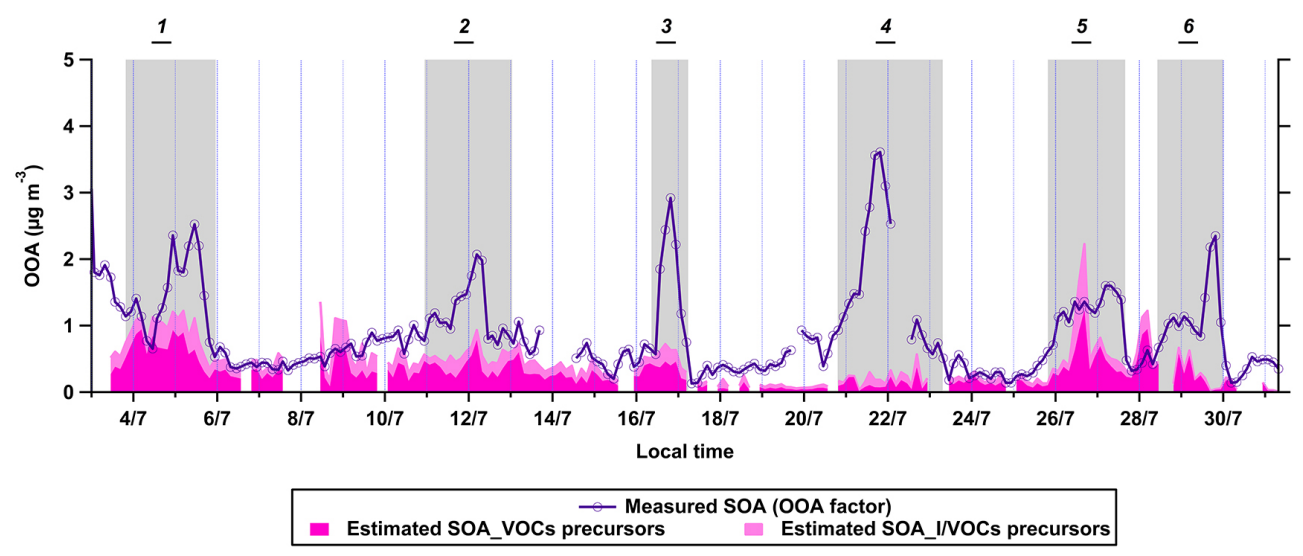

Figure 8. Temporal evolution of the OOA, or SOA, concentrations $\left(\mu \mathrm{g} \mathrm{m}^{-3}\right)$ (1) observed at SIRTA, (2) estimated from the VOCs and (3) from the I/ VOCs (i.e., VOCs $+\mathrm{C}_{12}-\mathrm{C}_{16}$ IVOCs) measured at SIRTA using atmospheric-relevant SOA yields. The grey-shaded areas highlight the "Atlantic Polluted" wind regimes associated with stagnant conditions and increased OOA.

VOCs and $\mathrm{C}_{12}-\mathrm{C}_{16} n$-alkane IVOCs. During this latter event, the air mass passed over Spain and the Landes Forest (Freutel et al., 2013a; Zhang et al., 2013), where biogenic precursor compounds are strongly emitted. Thus, one can hypothesize that biogenic SOA could have been transported from the southwest of France to the SIRTA site, but this biogenic fraction is not taken into account by the time-resolved approach. A noticeable overestimation of the SOA mass is observed during event 5, due to high IVOCs' mixing ratios (Fig. 3). The hexadecane mixing ratio can reach up to $126 \mathrm{ppt}$, which is 6 times more than its mean mixing ratio $(22 \pm 19 \mathrm{ppt}$, Table 3) and only a third of the toluene mixing ratio in the same sample (344 ppt). Hence, since the SOA yield formation of hexadecane is at least equal to those of toluene ( $\mathrm{Ng}$ et al., 2007a; Presto et al., 2010), the SOA estimation is mainly driven by the measured IVOCs, especially hexadecane, during event 5 . Therefore, contribution of the measured IVOCs can overtake the aromatics contribution to SOA formation.

When SIRTA is influenced by "Atlantic Clean" air masses, some overestimation of the SOA mass concentration can be observed, such as between July 8th and 10th. Besides these overestimations, the SIRTA site appears to be characterized by local SOA formation under the influence of "Atlantic Clean" air masses. During these periods, the SOA estimations appear to be of the same order as the SOA observations.

Estimated SOA from VOCs and IVOCs from the timeresolved approach are reported in Fig. 6. When compared to the results of the integrated approach, overall estimated SOA from VOCs and/or IVOCs is lower from the timeresolved approach than from the integrated approach using atmospheric-relevant SOA yields. This difference results from the amount of precursor taken into account for the estimation (Sects. 5.2.1 and 5.2.2). The time-resolved approach considers only the precursor fraction that has reacted, while the integrated approach estimates SOA formation from the overall precursor's quantity.

\subsubsection{Discussion}

With both of the two approaches, the SOA estimation is significantly improved when the $\mathrm{C}_{12}-\mathrm{C}_{16} n$-alkane IVOCs are taken into account. When considering the estimations based on the SOA yields of atmospheric relevancy, 2 and $7 \%$ improvement in the estimation of the formed SOA and of the SOA variability, respectively, are observed, when the IVOC alkanes are included in the estimation. IVOCs, especially $n$-alkanes, have been identified as important SOA precursors in past studies, whether they were chamber experiments (Lim and Ziemann, 2005, 2009a; Tkacik et al., 2012) or modeling (Jordan et al., 2008; Hodzic et al., 2010; Aumont et al., 2012; Pye and Pouliot, 2012). Our results confirm for the first time the important role of lower-volatility organic compounds in the SOA formation from their direct ambient measurements. However, when considering the integrated approach, $50 \mu \mathrm{g} \mathrm{m}^{-3} \mathrm{ppmv}^{-1}$, in other words, $62 \%$ of the measured SOA, remain unexplained. Similar results were found by Freney et al. (2014). By implementing a similar integrated approach from OM and anthropogenic VOCs' airborne measurements performed in the Paris plume during the same MEGAPOLI summer experiment, Freney et al. (2014) explained $54 \%$ of the SOA formation. When compared to the semi-volatile fraction of OOA, the SOA estimation (2014) from both Freney et al. and ourselves are consistent with SV-OOA, which represents $56 \%$ of OOA; we both estimated the freshest OOA. When considering the time-resolved approach, important underestimations of SOA are observed, especially when the SIRTA receives "Atlantic Polluted" air masses. Part of the SOA measured in suburban Paris therefore remains unexplained. Following de Gouw et al. (2008) and various assumptions discussed in Sect. 5.1.3, possible explanations are uncertainties in the SOA yields, the exclusion of the biogenic compounds, significant unidentified mass in the $\mathrm{C}_{10}-\mathrm{C}_{20}$ range, known as the unresolved 
complex mixture (UCM) (Robinson et al., 2007), as well as other non-measured compounds of lower volatility $>\mathrm{C}_{16}$. In this study, the exclusion of biogenic compounds certainly leads to an underestimation of the SOA formed. Indeed, simulations by Zhang et al. (2013) with the CHIMERE model, including the volatility basis set, have demonstrated that biogenic SOA has been transported to the Paris agglomeration from the south of France and Spain in "Atlantic Polluted" air masses. They estimated that $60 \%$ of the SOA is of biogenic origin during these events. During the whole month of July, the Zhang et al. study estimates the contribution of biogenic VOCs, of anthropogenic VOCs and of the sum of IVOCs and semi-volatile organic compounds to SOA at SIRTA as respectively 47, 23 and $13 \%$ (17\% being attributed to longrange-transported SOA from outside the European model domain). If all missing SOA is tentatively attributed to biogenic SOA and long-range-transported SOA, the corresponding values from our study, respectively, are $62-78,36-15$ and 2-7\% (integrated approach-time-resolved approach). Thus the modeling and our experimental results, with both their specific uncertainties, agree well.

However, our estimation of the IVOC part is still underestimated. Even though some IVOCs were taken into account here $\left(\mathrm{C}_{12}-\mathrm{C}_{16} n\right.$-alkanes), numerous compounds of lower volatility, such as $n$-alkanes with more than 16 carbon atoms, cyclic alkanes or PAHs (polyaromatic hydrocarbons), were not measured, while they could contribute significantly to the SOA formation (Chan et al., 2009; Lim and Ziemann, 2009a; Yuan et al., 2013). Furthermore, these compounds are expected to be largely emitted by diesel cars (Schauer et al., 1999a; Chan et al., 2009; Gentner et al., 2012), which are widely used in France (CCFA, 2011). Measurements of more IVOCs and other compounds of lower volatility might improve the SOA estimation from the integrated approach. Hence, efforts should be made to make the IVOC measurements as systematic as the measurements of other compounds, like the aromatic VOCs (e.g., during field experiments).

\section{Conclusions}

Under the auspices of the MEGAPOLI project, measurements of gaseous organic carbon have been performed in the Paris megacity, resulting in a large and unique database (available at the French Ether database: http://ether.ipsl. jussieu.fr/megapoli/). Compounds of different sources and chemical and physical properties have been documented during a summer and a winter field campaign at SIRTA, a suburban site of the French megacity.

The first goal was to analyze the temporal and spatial variability and origin of gaseous organic carbon in suburban Paris. The analysis showed that

- The seasonal variation of anthropogenic VOCs is the one usually depicted in urban areas with higher winter- time concentrations as a result of a combination of (i) a shallower boundary layer in winter than in summer, (ii) photochemistry processes less active in winter and (iii) emissions sources of different nature and/or intensity.

- The seasonal variation of $\mathrm{C}_{12}-\mathrm{C}_{16} n$-alkanes of intermediate volatility follows an opposite trend to traditional anthropogenic VOCs with lower concentrations in winter. The variation of these compounds mixing ratios probably results from a change in their emission sources (type, strength) than from the partition to the gas-phase to the particulate-phase of these lower volatility species.

- The seasonal variations of OVOCs shows a different behavior than usually observed with lower concentrations in summer, suggesting their dominant primary origin.

- The seasonal variation of $\alpha$-pinene and isoprene, with higher concentrations in summer is typical of biogenicemitted compounds. On the contrary, camphene and limonene exhibit higher concentrations in winter than in summer, suggesting weaker loss processes and/or additional anthropogenic emission sources to their biogenic ones.

The VOC levels at SIRTA are very low compared to other cities worldwide and are similar to the ones encountered in remote atmospheres. Like other atmospheric species in the whole Paris area, and organic aerosol in particular, meteorology and air mass origin strongly influence the variability of atmospheric species.

The second goal was to estimate the contribution of measured I / VOC precursors to SOA formation by implementing two independent approaches (integrated and time-resolved). Between 15 and $36 \%$ of the SOA measured was explained by the measurements of the only volatile compounds (aromatics and $\mathrm{C}_{9}-\mathrm{C}_{11} n$-alkanes) from both approaches. The IVOCs $\left(\mathrm{C}_{12}-\mathrm{C}_{16} n\right.$-alkanes) explain 2 to $7 \%$ of the SOA formation. Finally, between 22 and $38 \%$ of SOA observed at SIRTA was explained by observations. These values are consistent with the ones simulated with a chemistry-transport model, in which the volatility set basis has been implemented. They are also consistent with the results of a similar integrated approach using airborne measurements of organic compounds in the Paris area. From the time-resolved approach, the temporal estimation of the SOA formation indicated that the primary anthropogenic I/ VOCs are greatly involved in the formation of the SOA background at SIRTA. But important discrepancies between the estimation and the observation remain during events of high SOA mass concentration. The estimations indicate that the SOA concentrations measured at SIRTA are not only strongly dependent (i) on the primary anthropogenic VOCs, which are widely measured around the world, but also (ii) on the IVOCs, since only five of them explain more than $10 \%$ of the observed SOA, 
(iii) on other compounds which were not included in the estimation because they were not measured or because they were not from primary anthropogenic sources, and finally (iv) on SOA transported over long distances for which the signature in gaseous precursors is lost. Thus, further investigations should be undertaken in order to take into account these compounds, either by developing their measurements (as for additional IVOCs), determining SOA yields in relevant atmospheric conditions or by including them in the estimations (as for biogenic SOA relying on specific tracers in both the gas and particle phase).

\section{The Supplement related to this article is available online at doi:10.5194/acp-14-10439-2014-supplement.}

Acknowledgements. The research leading to these results has received funding from the European Union's Seventh Framework Program FP/2007-2011 under grant agreement no. 212520. Support from the French ANR project MEGAPOLI - PARIS (ANR-09BLAN-0356), from the French ADEME via the CNRS-INSU/LEFE program is acknowledged. This research work has been supported by the European Community within the seventh Framework Program: Eurochamp-2 (EU-FP7 grant agreement no. 228335).

The authors acknowledge ADEME and the Fulbright Commission for their financial support to W. Ait-Helal doctoral researches. The authors acknowledge M. Haeffelin, the SIRTA and the LHVP team for their technical support. R. Sarda-Estève and J. Nicolas are kindly acknowledged for the CO measurements at SIRTA. The authors also thank Tera Environnement for lending the sampling systems. The authors thankfully acknowledge A. Stohl, J. F. Burkhart and S. Eckhardt for the FLEXPART simulations. Finally, the authors thank all the people who helped with their insights on the data and its analysis: F. Oztürk and R. Bahreini for all the discussions on the particulate matter and its measurement by AMS, P. Ziemann for the kind help on the SOA yield of IVOCs. The French ether database (http://ether.ipsl.jussieu.fr/megapoli/) is acknowledged for hosting the experimental data.

Edited by: C. Reeves

\section{References}

Aiken, A. C., Salcedo, D., Cubison, M. J., Huffman, J. A., DeCarlo, P. F., Ulbrich, I. M., Docherty, K. S., Sueper, D., Kimmel, J. R., Worsnop, D. R., Trimborn, A., Northway, M., Stone, E. A., Schauer, J. J., Volkamer, R. M., Fortner, E., de Foy, B., Wang, J., Laskin, A., Shutthanandan, V., Zheng, J., Zhang, R., Gaffney, J., Marley, N. A., Paredes-Miranda, G., Arnott, W. P., Molina, L. T., Sosa, G., and Jimenez, J. L.: Mexico City aerosol analysis during MILAGRO using high resolution aerosol mass spectrometry at the urban supersite (T0) - Part 1: Fine particle composition and organic source apportionment, Atmos. Chem. Phys., 9, 6633-6653, doi:10.5194/acp-9-6633-2009, 2009.

Aiken, A. C., de Foy, B., Wiedinmyer, C., DeCarlo, P. F., Ulbrich, I. M., Wehrli, M. N., Szidat, S., Prevot, A. S. H., Noda, J., Wacker,
L., Volkamer, R., Fortner, E., Wang, J., Laskin, A., Shutthanandan, V., Zheng, J., Zhang, R., Paredes-Miranda, G., Arnott, W. P., Molina, L. T., Sosa, G., Querol, X., and Jimenez, J. L.: Mexico city aerosol analysis during MILAGRO using high resolution aerosol mass spectrometry at the urban supersite (T0) Part 2: Analysis of the biomass burning contribution and the non-fossil carbon fraction, Atmos. Chem. Phys., 10, 5315-5341, doi:10.5194/acp-10-5315-2010, 2010.

Allan, J. D., Williams, P. I., Morgan, W. T., Martin, C. L., Flynn, M. J., Lee, J., Nemitz, E., Phillips, G. J., Gallagher, M. W., and Coe, H.: Contributions from transport, solid fuel burning and cooking to primary organic aerosols in two UK cities, Atmos. Chem. Phys., 10, 647-668, doi:10.5194/acp-10-647-2010, 2010.

Anderson, H. R.: Air pollution and mortality: A history, Atmos. Environ., 43, 142-152, 2009.

Atkinson, R.: Kinetics and mechanisms of the gas-phase reactions of the hydroxyl radical with organic compounds under atmospheric conditions, Chem. Rev., 86, 69-201, 1986.

Atkinson, R. and Arey, J.: Atmospheric Degradation of Volatile Organic Compounds, Chem. Rev., 103, 4605-4638, 2003.

Aumont, B., Valorso, R., Mouchel-Vallon, C., Camredon, M., LeeTaylor, J., and Madronich, S.: Modeling SOA formation from the oxidation of intermediate volatility $n$-alkanes, Atmos. Chem. Phys., 12, 7577-7589, doi:10.5194/acp-12-7577-2012, 2012.

Badol, C., Locoge, N., Léonardis, T., and Galloo, J.-C.: Using a source-receptor approach to characterise VOC behaviour in a French urban area influenced by industrial emissions Part I: Study area description, data set acquisition and qualitative data analysis of the data set, Sci. Total Environ., 389, 441-452, 2008.

Bakeas, E. B., Argyris, D. I. and Siskos, P. A.: Carbonyl compounds in the urban environment of Athens, Greece, Chemosphere, 52, 805-813, 2003.

Balzani Lööv, J. M., Henne, S., Legreid, G., Staehelin, J., Reimann, S., Prévôt, A. S. H., Steinbacher, M., and Vollmer, M. K.: Estimation of background concentrations of trace gases at the Swiss Alpine site Jungfraujoch (3580 m asl), J. Geophys. Res., 113, D22305, doi:10.1029/2007JD009751, 2008.

Barletta, B., Meinardi, S., Simpson, I. J., Khwaja, H. A., Blake, D. R., and Rowland, F. S.: Mixing ratios of volatile organic compounds (VOCs) in the atmosphere of Karachi, Pakistan, Atmos. Environ., 36, 3429-3443, 2002.

Bates, M. S., Gonzalez-Flesca, N., Sokhi, R., and Cocheo, V.: Atmospheric Volatile Organic Compound Monitoring. Ozone Induced Artefact Formation, Environ. Monit. Assess., 65, 89-97, 2000.

Baumbach, G., Vogt, U., Hein, K. R. G., Oluwole, A. F., Ogunsola, O. J., Olaniyi, H. B., and Akeredolu, F. A.: Air pollution in a large tropical city with a high traffic density - results of measurements in Lagos, Nigeria, Sci. Total Environ., 169, 25-31, 1995.

Bi, X., Sheng, G., Peng, P., Chen, Y., Zhang, Z., and Fu, J.: Distribution of particulate- and vapor-phase $n$-alkanes and polycyclic aromatic hydrocarbons in urban atmosphere of Guangzhou, China, Atmos. Environ., 37, 289-298, 2003.

Bon, D. M., Ulbrich, I. M., de Gouw, J. A., Warneke, C., Kuster, W. C., Alexander, M. L., Baker, A., Beyersdorf, A. J., Blake, D., Fall, R., Jimenez, J. L., Herndon, S. C., Huey, L. G., Knighton, W. B., Ortega, J., Springston, S., and Vargas, O.: Measurements of volatile organic compounds at a suburban ground site (T1) in Mexico City during the MILAGRO 2006 campaign: mea- 
surement comparison, emission ratios, and source attribution, Atmos. Chem. Phys., 11, 2399-2421, doi:10.5194/acp-11-23992011, 2011.

Borbon, A., Fontaine, H., Veillerot, M., Locoge, N., Galloo, J. C., and Guillermo, R.: An investigation into the traffic-related fraction of isoprene at an urban location, Atmos. Environ., 35, 37493760, 2001.

Borbon, A., Locoge, N., Veillerot, M., Galloo, J. C., and Guillermo, R.: Characterisation of NMHCs in a French urban atmosphere: overview of the main sources, Sci. Total Environ., 292, 177-191, 2002.

Borbon, A., Fontaine, H., Locoge, N., Veillerot, M., and Galloo, J. C.: Developing receptor-oriented methods for non-methane hydrocarbon characterisation in urban air - Part I: source identification, Atmos. Environ., 37, 4051-4064, 2003.

Borbon, A., Gilman, J. B., Kuster, W. C., Grand, N., Chevaillier, S., Colomb, A., Dolgorouky, C., Gros, V., Lopez, M., SardaEsteve, R., Holloway, J., Stutz, J., Petetin, H., McKeen, S., Beekmann, M., Warneke, C., Parrish, D. D., and De Gouw, J. A.: Emission ratios of anthropogenic volatile organic compounds in northern mid-latitude megacities: Observations versus emission inventories in Los Angeles and Paris, J. Geophys. Res., 118, 117, doi:10.1002/jgrd.50059, 2013.

Boudries, H., Toupance, G., and Dutot, A. L.: Seasonal variation of atmospheric nonmethane hydrocarbons on the western coast of Brittany, France, Atmos. Environ., 28, 1095-1112, 1994.

Boynard, A., Borbon, A., Leonardis, T., Barletta, B., Meinardi, S., Blake, D. R., and Locoge, N.: Spatial and seasonal variability of measured anthropogenic non-methane hydrocarbons in urban atmospheres: Implication on emission ratios, Atmos. Environ., 82, 258-267, 2014.

Carlton, A. G., Turpin, B. J., Altieri, K. E., Seitzinger, S. P., Mathur, R., Roselle, S. J., and Weber, R. J.: CMAQ Model Performance Enhanced When In-Cloud Secondary Organic Aerosol is Included: Comparisons of Organic Carbon Predictions with Measurements, Environ. Sci. Technol., 42, 8798-8802, 2008.

CCFA - Comité des Constructeurs Français d'Automobiles: Analyses et statistiques: l'industrie automobile française (Analysis and statistics: the French Automotive Industry), France, 2011.

Cecinato, A., Yassaa, N., Di Palo, V., and Possanzini, M.: Observation of volatile and semi-volatile carbonyls in an Algerian urban environment using dinitrophenylhydrazine/silica-HPLC and pentafluorophenylhydrazine/silica-GC-MS, J. Environ. Monitor., 4, 223-228, 2002.

Chameides, W., Lindsay, R., Richardson, J., and Kiang, C.: The role of biogenic hydrocarbons in urban photochemical smog: Atlanta as a case study, Science, 241, 1473-1475, 1988.

Chan, A. W. H., Kautzman, K. E., Chhabra, P. S., Surratt, J. D., Chan, M. N., Crounse, J. D., Kürten, A., Wennberg, P. O., Flagan, R. C., and Seinfeld, J. H.: Secondary organic aerosol formation from photooxidation of naphthalene and alkylnaphthalenes: implications for oxidation of intermediate volatility organic compounds, (IVOCs), Atmos. Chem. Phys., 9, 3049-3060, doi:10.5194/acp-9-3049-2009, 2009.

Cheng, L., Fu, L., Angle, R. P., and Sandhu, H. S.: Seasonal variations of volatile organic compounds in Edmonton, Alberta, Atmos. Environ., 31, 239-246, 1997.

Coe, H.: Aerosol Chemistry and the Deepwater Horizon Spill, Science, 331, 1273-1274, 2011.
Colón, M., Pleil, J. D., Hartlage, T. A., Guardani, M. L., and Martins, M. H.: Survey of volatile organic compounds associated with automotive emissions in the urban airshed of Sao Paulo, Brazil, Atmos. Environ., 35, 4017-4031, 2001.

Cozic, J., Verheggen, B., Weingartner, E., Crosier, J., Bower, K. N., Flynn, M., Coe, H., Henning, S., Steinbacher, M., Henne, S., Collaud Coen, M., Petzold, A., and Baltensperger, U.: Chemical composition of free tropospheric aerosol for $\mathrm{PM}_{1}$ and coarse mode at the high alpine site Jungfraujoch, Atmos. Chem. Phys., 8, 407-423, doi:10.5194/acp-8-407-2008, 2008.

Crippa, M., DeCarlo, P. F., Slowik, J. G., Mohr, C., Heringa, M. F., Chirico, R., Poulain, L., Freutel, F., Sciare, J., Cozic, J., Di Marco, C. F., Elsasser, M., Nicolas, J. B., Marchand, N., Abidi, E., Wiedensohler, A., Drewnick, F., Schneider, J., Borrmann, S., Nemitz, E., Zimmermann, R., Jaffrezo, J.-L., Prévôt, A. S. H., and Baltensperger, U.: Wintertime aerosol chemical composition and source apportionment of the organic fraction in the metropolitan area of Paris, Atmos. Chem. Phys., 13, 961-981, doi:10.5194/acp-13-961-2013, 2013a.

Crippa, M., El Haddad, I., Slowik, J. G., DeCarlo, P. F., Mohr, C., Heringa, M. F., Chirico, R., Marchand, N., Sciare, J., Baltensperger, U., and Prévôt, A. S. H.: Identification of marine and continental aerosol sources in Paris using high resolution aerosol mass spectrometry, J. Geophys. Res., 118, 1950-1963, doi:10.1002/jgrd.50151, 2013 b.

Dallmann, T. R., Kirchstetter, T. W., DeMartini, S. J., and Harley, R. A.: Quantifying On-Road Emissions from Gasoline-Powered Motor Vehicles: Accounting for the Presence of Medium- and Heavy-Duty Diesel Trucks, Environ. Sci. Technol., 47, 1387313881, doi:10.1021/es402875u, 2013.

de Gouw, J.A., Middlebrook, A. M., Warneke, C., Goldan, P. D., Kuster, W. C., Roberts, J. M., Fehsenfeld, F. C., Worsnop, D. R., Canagaratna, M. R., Pszenny, A. A. P., Keene, W. C., Marchewka, M., Bertman, S. B., and Bates, T. S.: Budget of organic carbon in a polluted atmosphere: Results from the New England Air Quality Study in 2002. J. Geophys. Res., 110, D16305, doi:10.1029/2004JD005623, 2005.

de Gouw, J.A., Brock, C. A., Atlas, E. L., Bates, T. S., Fehsenfeld, F. C., Goldan, P. D., Holloway, J. S., Kuster, W. C., Lerner, B. M., Matthew, B. M., Middlebrook, A. M., Onasch, T. B., Peltier, R. E., Quinn, P. K., Senff, C. J., Stohl, A., Sullivan, A. P., Trainer, M., Warneke, C., Weber, R. J., and Williams, E. J.: Sources of particulate matter in the northeastern United States in summer: 1. Direct emissions and secondary formation of organic matter in urban plumes. J. Geophys. Res., 113, D08301, doi:10.1029/2007JD009243, 2008.

de Gouw, J. A., Welsh-Bon, D., Warneke, C., Kuster, W. C., Alexander, L., Baker, A. K., Beyersdorf, A. J., Blake, D. R., Canagaratna, M., Celada, A. T., Huey, L. G., Junkermann, W., Onasch, T. B., Salcido, A., Sjostedt, S. J., Sullivan, A. P., Tanner, D. J., Vargas, O., Weber, R. J., Worsnop, D. R., Yu, X. Y., and Zaveri, R.: Emission and chemistry of organic carbon in the gas and aerosol phase at a sub-urban site near Mexico City in March 2006 during the MILAGRO study, Atmos. Chem. Phys., 9, 34253442, doi:10.5194/acp-9-3425-2009, 2009.

de Gouw, J. A., Middlebrook, A. M., Warneke, C., Ahmadov, R., Atlas, E. L., Bahreini, R., Blake, D. R., Brock, C. A., Brioude, J., Fahey, D. W., Fehsenfeld, F. C., Holloway, J. S., Le Henaff, M., Lueb, R. A., McKeen, S. A., Meagher, J. F., Murphy, D. M., 
Paris, C., Parrish, D. D., Perring, A. E., Pollack, I. B., Ravishankara, A. R., Robinson, A. L., Ryerson, T. B., Schwarz, J. P., Spackman, J. R., Srinivasan, A., and Watts, L. A.: Organic Aerosol Formation Downwind from the Deepwater Horizon Oil Spill, Science, 331, 1295-1299, 2011.

DeCarlo, P. F., Kimmel, J. R., Trimborn, A., Northway, M. J., Jayne, J. T., Aiken, A. C., Gonin, M., Fuhrer, K., Horvath, T., Docherty, K. S., Worsnop, D. R., and Jimenez, J. L.: Field-Deployable, High-Resolution, Time-of-Flight Aerosol Mass Spectrometer, Anal. Chem., 78, 8281-8289, 2006.

Detournay, A., Sauvage, S., Locoge, N., Gaudion, V., Leonardis, T., Fronval, I., Kaluzny, P., and Galloo, J.-C.: Development of a sampling method for the simultaneous monitoring of straightchain alkanes, straight-chain saturated carbonyl compounds and monoterpenes in remote areas. J. Environ. Monitor., 13, 983990, 2011.

Detournay, A., Sauvage, S., Riffault, V., Wroblewski, A., and Locoge, N.: Source and behavior of isoprenoid compounds at a southern France remote site, Atmos. Environ., 77, 272-282, 2013.

Dettmer, K. and Engewald, W.: Ambient air analysis of volatile organic compounds using adsorptive enrichment, Chromatographia, 57, S339-S347, 2003.

Dockery, D.W., Pope, C. A., Xu, X., Spengler, J. D., Ware, J. H., Fay, M. E., Ferris, B. G. and Speizer, F. E.:An Association between Air Pollution and Mortality in Six U.S. Cities. New Engl. J. Med., 329, 1753-1759, 1993.

Dommen, J., Prévôt, A. S. H., Neininger, B., and Clark, N.: $\mathrm{NO}_{\mathrm{x}}$ TOy: a miniaturised new instrument for reactive nitrogen oxides in the atmosphere, PSI Scientific Report 1999, Volume V, Paul Scherrer Institute, 2000.

Duan, J., Tan, J., Yang, L., Wu, S., and Hao, J.: Concentration, sources and ozone formation potential of volatile organic compounds (VOCs) during ozone episode in Beijing, Atmos. Res., $88,25-35,2008$.

Dutta, C., Chatterjee, A., Jana, T. K., Mukherjee, A. K., and Sen, S.: Contribution from the primary and secondary sources to the atmospheric formaldehyde in Kolkata, India, Sci. Total Environ., 408, 4744-4748, 2010.

Epstein, S. A., Riipinen, I., and Donahue, N. M.: A Semiempirical Correlation between Enthalpy of Vaporization and Saturation Concentration for Organic Aerosol, Environ. Sci. Technol., 44, 743-748, doi:10.1021/es902497z, 2010.

Ervens, B., Turpin, B. J., and Weber, R. J.: Secondary organic aerosol formation in cloud droplets and aqueous particles (aqSOA): a review of laboratory, field and model studies, Atmos. Chem. Phys., 11, 11069-11102, doi:10.5194/acp-1111069-2011, 2011.

Favez, O., Cachier, H., Sciare, J., and Moullec, Y. L.: Characterization and contribution to PM2.5 of semi-volatile aerosols in Paris (France), Atmos. Environ., 41, 7969-7976, 2007.

Filella, I. and Peñuelas, J.: Daily, weekly, and seasonal time courses of VOC concentrations in a semi-urban area near Barcelona, Atmos. Environ., 40, 7752-7769, 2006.

Filleul, L., Cassadou, S., Médina, S., Fabres, P., Lefranc, A., Eilstein, D., Tertre, A. L., Pascal, L., Chardon, B., Blanchard, M., Declerq, C., Jusot, J.-F., Prouvost, H., and Ledrans, M.: The relation between temperature, ozone, and mortality in nine French cities during the heat wave of 2003, Environ. Health Persp., 114, 1344-1347, 2006.

Finkelstein, M. M., Jerrett, M., and Sears, M. R.: Traffic Air Pollution and Mortality Rate Advancement Periods, Am. J. Epidemiol., 160, 173-177, 2004.

Fontaine, H.: Les Composés Organiques Volatils dans les gaz d'échappement des automobiles: etablissement de profils d'émission représentatifs de différentes conditions de conduite, Ph.D. thesis, Université de Technologie de Compiègne, France, 288 pp., 2000

Fraser, M. P., Cass, G. R., and Simoneit, B. R. T.: Gas-Phase and Particle-Phase Organic Compounds Emitted from Motor Vehicle Traffic in a Los Angeles Roadway Tunnel, Environ. Sci. Technol., 32, 2051-2060, doi:10.1021/es970916e, 1998.

Freney, E. J., Sellegri, K., Canonaco, F., Colomb, A., Borbon, A., Michoud, V., Doussin, J.-F., Crumeyrolle, S., Amarouche, N., Pichon, J.-M., Bourianne, T., Gomes, L., Prévôt, A. S. H., Beekmann, M., and Schwarzenböeck, A.: Characterizing the impact of urban emissions on regional aerosol particles: airborne measurements during the MEGAPOLI experiment, Atmos. Chem. Phys., 14, 1397-1412, doi:10.5194/acp-14-1397-2014, 2014.

Freutel, F., Schneider, J., Drewnick, F., von der Weiden-Reinmüller, S.-L., Crippa, M., Prévôt, A. S. H., Baltensperger, U., Poulain, L., Wiedensohler, A., Sciare, J., Sarda-Estève, R., Burkhart, J. F., Eckhardt, S., Stohl, A., Gros, V., Colomb, A., Michoud, V., Doussin, J. F., Borbon, A., Haeffelin, M., Morille, Y., Beekmann, M., and Borrmann, S.: Aerosol particle measurements at three stationary sites in the megacity of Paris during summer 2009: Meteorology and air mass origin dominate aerosol particle composition and size distribution, Atmos. Chem. Phys., 13, 933-959, doi:10.5194/acp-13-933-2013, 2013a.

Freutel, F., Drewnick, F., Schneider, J., Klimach, T., and Borrmann, S.: Quantitative single-particle analysis with the Aerodyne aerosol mass spectrometer: development of a new classification algorithm and its application to field data, Atmos. Meas. Tech., 6, 3131-3145, doi:10.5194/amt-6-3131-2013, $2013 \mathrm{~b}$.

Fry, J. L., Kiendler-Scharr, A., Rollins, A. W., Wooldridge, P. J., Brown, S. S., Fuchs, H., Dubé, W., Mensah, A., Dal Maso, M., Tillmann, R., Dorn, H.-P., Brauers, T., and Cohen, R. C.: Organic nitrate and secondary organic aerosol yield from $\mathrm{NO}_{3}$ oxidation of $\beta$-pinene evaluated using a gas-phase kinetics/aerosol partitioning model, Atmos. Chem. Phys., 9, 14311449, doi:10.5194/acp-9-1431-2009, 2009.

Fry, J. L., Kiendler-Scharr, A., Rollins, A. W., Brauers, T., Brown, S. S., Dorn, H.-P., Dubé, W. P., Fuchs, H., Mensah, A., Rohrer, F., Tillmann, R., Wahner, A., Wooldridge, P. J., and Cohen, R. C.: SOA from limonene: role of $\mathrm{NO}_{3}$ in its generation and degradation, Atmos. Chem. Phys., 11, 3879-3894, doi:10.5194/acp-113879-2011, 2011.

Gaeggeler, K., Prevot, A. S. H., Dommen, J., Legreid, G., Reimann, S., and Baltensperger, U.: Residential wood burning in an Alpine valley as a source for oxygenated volatile organic compounds, hydrocarbons and organic acids, Atmos. Environ., 42, 82788287, 2008.

Gaimoz, C., Sauvage, S., Gros, V., Herrmann, F., Williams, J., Locoge, N., Perrussel, O., Bonsang, B., d'Argouges, O., SardaEstève, R., and Sciare, J.: Volatile organic compounds sources in Paris in spring 2007. Part II: source apportionment using positive matrix factorisation, Environ. Chem., 8, 91-103, 2011. 
Gentner, D. R., Harley, R. A., Miller, A. M., and Goldstein, A. H.: Diurnal and Seasonal Variability of Gasoline-Related Volatile Organic Compound Emissions in Riverside, California, Environ. Sci. Technol., 43, 4247-4252, doi:10.1021/es9006228, 2009.

Gentner, D. R., Isaacman, G., Worton, D. R., Chan, A. W. H., Dallmann, T. R., Davis, L., Liu, S., Day, D. A., Russell, L. M., Wilson, K. R., Weber, R., Guha, A., Harley, R. A., and Goldstein, A. H.: Elucidating secondary organic aerosol from diesel and gasoline vehicles through detailed characterization of organic carbon emissions, P. Natl. Acad. Sci., 109, 18318-18323, doi:10.1073/pnas.1212272109, 2012.

Gentner, D. R., Worton, D. R., Isaacman, G., Davis, L. C., Dallmann, T. R., Wood, E. C., Herndon, S. C., Goldstein, A. H., and Harley, R. A.: Chemical Composition of Gas-Phase Organic Carbon Emissions from Motor Vehicles and Implications for Ozone Production, Environ. Sci. Technol., 47, 11837-11848, doi:10.1021/es401470e, 2013.

Gros, V., Bonsang, B., and Sarda Esteve, R.: Atmospheric carbon monoxide 'in situ' monitoring by automatic gas chromatography, Chemosphere, 1, 153-161, 1999.

Gros, V., Jöckel, P., Brenninkmeijer, C. A. M., Röckmann, T., Meinhardt, F., and Graul, R.: Characterization of pollution events observed at Schauinsland, Germany, using CO and its stable isotopes, Atmos. Environ., 36, 2831-2840, 2002.

Gros, V., Sciare, J., and Yu, T.: Air-quality measurements in megacities: Focus on gaseous organic and particulate pollutants and comparison between two contrasted cities, Paris and Beijing, C. R. Geosci., 339, 764-774, 2007.

Gros, V., Gaimoz, C., Herrmann, F., Custer, T., Williams, J., Bonsang, B., Sauvage, S., Locoge, N., d'Argouges, O., Sarda-Estève, R., and Sciare, J.: Volatile organic compounds sources in Paris in spring 2007. Part I: qualitative analysis, Environ. Chem., 8, 7490, 2011.

Grosjean, D., Grosjean, E., and Gertler, A. W.: On-Road Emissions of Carbonyls from Light-Duty and Heavy-Duty Vehicles, Environ. Sci. Technol., 35, 45-53, doi:10.1021/es001326a, 2001.

Guenther, A. B., Monson, R. K., and Fall, R.: Isoprene and Monoterpene Emission Rate Variability: Observations With Eucalyptus and Emission Rate Algorithm Development, J. Geophys. Res., 96, 10799-10808, doi:10.1029/91JD00960, 1991.

Guo, Z., Lin, T., Zhang, G., Hu, L., and Zheng, M.: Occurrence and sources of polycyclic aromatic hydrocarbons and $n$-alkanes in $\mathrm{PM}_{2.5}$ in the roadside environment of a major city in China, J. Hazard. Mater., 170, 888-894, 2009.

Haeffelin, M., Barthés, L., Bock, O., Boitel, C., Bony, S., Bouniol, D., Chepfer, H., Chiriaco, M., Cuesta, J., Delanoë, J., Drobinski, P., Dufresne, J.-L., Flamant, C., Grall, M., Hodzic, A., Hourdin, F., Lapouge, F., Lemaître, Y., Mathieu, A., Morille, Y., Naud, C., Noël, V., O'Hirok, W., Pelon, J., Pietras, C., Protat, A., Romand, B., Scialom, G., and Vautard, R.: SIRTA, a ground-based atmospheric observatory for cloud and aerosol research, Ann. Geophys., 23, 253-275, doi:10.5194/angeo-23-253-2005, 2005.

Haeffelin, M., Angelini, F., Morille, Y., Martucci, G., Frey, S., Gobbi, G. P., Lolli, S., O’Dowd, C. D., Sauvage, L., XuerefRémy, I., Wastine, B. and Feist, D. G.: Evaluation of MixingHeight Retrievals from Automatic Profiling Lidars and Ceilometers in View of Future Integrated Networks in Europe, Bound.Lay. Meteorol., 143, 49-75, 2012.
Hallquist, M., Wenger, J. C., Baltensperger, U., Rudich, Y., Simpson, D., Claeys, M., Dommen, J., Donahue, N. M., George, C., Goldstein, A. H., Hamilton, J. F., Herrmann, H., Hoffmann, T., Iinuma, Y., Jang, M., Jenkin, M. E., Jimenez, J. L., KiendlerScharr, A., Maenhaut, W., McFiggans, G., Mentel, T. F., Monod, A., Prévôt, A. S. H., Seinfeld, J. H., Surratt, J. D., Szmigielski, R. and Wildt, J.: The formation, properties and impact of secondary organic aerosol: current and emerging issues, Atmos. Chem. Phys., 9, 5155-5236, doi:10.5194/acp-9-5155-2009, 2009.

Heald, C. L., Jacob, D. J., Park, R. J., Russell, L. M., Huebert, B. J., Seinfeld, J. H., Liao, H. and Weber, R. J.: A large organic aerosol source in the free troposphere missing from current models, Geophys. Res. Lett., 32, L18809, doi:10.1029/2005GL023831, 2005.

Heeb, N. V., Forss, A.-M., and Bach, C.: Fast and quantitative measurement of benzene, toluene and C2-benzenes in automotive exhaust during transient engine operation with and without catalytic exhaust gas treatment, Atmos. Environ., 33, 205-215, 1999.

Heiden, A.C., Hoffmann, T., Kahl, J., Kley, D., Klockow, D., Langebartels, C., Mehlhorn, H., Sandermann, H., Schraudner, M., Schuh, G., and Wildt, J.: Emission of volatile organic compounds from ozone-exposed plants, Ecol. Appl., 9, 1160-1167, 1999.

Hellén, H., Hakola, H., Reissell, A., and Ruuskanen, T. M.: Carbonyl compounds in boreal coniferous forest air in Hyytiälä, Southern Finland, Atmos. Chem. Phys., 4, 1771-1780, doi:10.5194/acp-4-1771-2004, 2004.

Hellén, H., Tykkä, T., and Hakola, H.: Importance of monoterpenes and isoprene in urban air in northern Europe, Atmos. Environ., 59, 59-66, 2012.

Hildebrandt, L., Donahue, N. M., and Pandis, S. N.: High formation of secondary organic aerosol from the photo-oxidation of toluene, Atmos. Chem. Phys., 9, 2973-2986, doi:10.5194/acp-92973-2009, 2009.

Ho, K. F., Lee, S. C., Louie, P. K. K., and Zou, S. C.: Seasonal variation of carbonyl compound concentrations in urban area of Hong Kong, Atmos. Environ., 36, 1259-1265, 2002.

Hodzic, A., Jimenez, J. L., Madronich, S., Aiken, A. C., Bessagnet, B., Curci, G., Fast, J., Lamarque, J.-F., Onasch, T. B., Roux, G., Schauer, J. J., Stone, E. A., and Ulbrich, I. M.: Modeling organic aerosols during MILAGRO: importance of biogenic secondary organic aerosols, Atmos. Chem. Phys., 9, 6949-6981, doi:10.5194/acp-9-6949-2009, 2009.

Hodzic, A., Jimenez, J. L., Madronich, S., Canagaratna, M. R., DeCarlo, P. F., Kleinman, L., and Fast, J.: Modeling organic aerosols in a megacity: potential contribution of semi-volatile and intermediate volatility primary organic compounds to secondary organic aerosol formation, Atmos. Chem. Phys., 10, 5491-5514, doi:10.5194/acp-10-5491-2010, 2010.

Hoque, R. R., Khillare, P. S., Agarwal, T., Shridhar, V., and Balachandran, S.: Spatial and temporal variation of BTEX in the urban atmosphere of Delhi, India, Sci. Total Environ., 392, 30-40, 2008.

Hornbrook, R. S., Blake, D. R., Diskin, G. S., Fried, A., Fuelberg, H. E., Meinardi, S., Mikoviny, T., Richter, D., Sachse, G. W., Vay, S. A., Walega, J., Weibring, P., Weinheimer, A. J., Wiedinmyer, C., Wisthaler, A., Hills, A., Riemer, D. D. and Apel, E. C.: Observations of nonmethane organic compounds during ARCTAS - Part 1: Biomass burning emissions and plume enhance- 
ments, Atmos. Chem. Phys., 11, 11103-11130, doi:10.5194/acp11-11103-2011, 2011.

iREP, Registre français des Émissions Polluantes, available at: http: //www.pollutionsindustrielles.ecologie.gouv.fr/IREP/index.php (last access: October 2012), 2012.

Jenkin, M. E. and Hayman, G. D.: Photochemical ozone creation potentials for oxygenated volatile organic compounds: sensitivity to variations in kinetic and mechanistic parameters, Atmos. Environ., 33, 1275-1293, 1999.

Jimenez, J. L., Canagaratna, M. R., Donahue, N. M., Prevot, A. S. H., Zhang, Q., Kroll, J. H., DeCarlo, P. F., Allan, J. D., Coe, H., Ng, N. L., Aiken, A. C., Docherty, K. S., Ulbrich, I. M., Grieshop, A. P., Robinson, A. L., Duplissy, J., Smith, J. D., Wilson, K. R., Lanz, V. A., Hueglin, C., Sun, Y. L., Tian, J., Laaksonen, A., Raatikainen, T., Rautiainen, J., Vaattovaara, P., Ehn, M., Kulmala, M., Tomlinson, J. M., Collins, D. R., Cubison, M. J., Dunlea, J., Huffman, J. A., Onasch, T. B., Alfarra, M. R., Williams, P. I., Bower, K., Kondo, Y., Schneider, J., Drewnick, F., Borrmann, S., Weimer, S., Demerjian, K., Salcedo, D., Cottrell, L., Griffin, R., Takami, A., Miyoshi, T., Hatakeyama, S., Shimono, A., Sun, J. Y., Zhang, Y. M., Dzepina, K., Kimmel, J. R., Sueper, D., Jayne, J. T., Herndon, S. C., Trimborn, A. M., Williams, L. R., Wood, E. C., Middlebrook, A. M., Kolb, C. E., Baltensperger, U., and Worsnop, D. R., Evolution of Organic Aerosols in the Atmosphere, Science, 326, 1525-1529, 2009.

Jordan, C. E., Ziemann, P. J., Griffin, R. J., Lim, Y. B., Atkinson, R., and Arey, J.: Modeling SOA formation from $\mathrm{OH}$ reactions with C8-C17 n-alkanes, Atmos. Environ., 42, 8015-8026, 2008.

Kadowaki, S.: Characterization of carbonaceous aerosols in the Nagoya urban area. 2. Behavior and origin of particulate $n$-alkanes, Environ. Sci. Technol., 28, 129-135, doi:10.1021/es00050a017, 1994

Kanakidou, M., Seinfeld, J. H., Pandis, S. N., Barnes, I., Dentener, F. J., Facchini, M. C., Van Dingenen, R., Ervens, B., Nenes, A., Nielsen, C. J., Swietlicki, E., Putaud, J. P., Balkanski, Y., Fuzzi, S., Horth, J., Moortgat, G. K., Winterhalter, R., Myhre, C. E. L., Tsigaridis, K., Vignati, E., Stephanou, E. G. and Wilson, J.: Organic aerosol and global climate modelling: a review, Atmos. Chem. Phys., 5, 1053-1123, doi:10.5194/acp-5-1053-2005, 2005.

Kappos, A.D., Bruckmann, P., Eikmann, T., Englert, N., Heinrich, U., Höppe, P., Koch, E., Krause, G. H. M., Kreyling, W. G., Rauchfuss, K., Rombout, P., Schulz-Klemp, V., Thiel, W. R., and Wichmann, H.-E.: Health effects of particles in ambient air, Int. J. Hy. Envir. Heal., 207, 399-407, 2004.

Khillare, P. S., Hoque, R. R., Shridhar, V., Agarwal, T., and Balachandran, S.: Temporal variability of benzene concentration in the ambient air of Delhi: A comparative assessment of pre- and post-CNG periods, J. Hazard. Mater., 154, 1013-1018, 2008.

Khoder, M. I.: Ambient levels of volatile organic compounds in the atmosphere of Greater Cairo, Atmos. Environ., 41, 554-566, 2007.

Kleindienst, T. E., Corse, E. W., Blanchard, F. T., and Lonneman, W. A.: Evaluation of the Performance of DNPH-Coated Silica Gel and C18 Cartridges in the Measurement of Formaldehyde in the Presence and Absence of Ozone, Environ. Sci. Technol., 32, 124-130, doi:10.1021/es970205g, 1998.

Kleindienst, T. E., Jaoui, M., Lewandowski, M., Offenberg, J. H., Lewis, C. W., Bhave, P. V., and Edney, E. O.: Estimates of the contributions of biogenic and anthropogenic hydrocarbons to secondary organic aerosol at a southeastern US location, Atmos. Environ., 41, 8288-8300, 2007.

Knobloch, T., Asperger, A., and Engewald, W.: Volatile organic compounds in urban atmospheres: Long-term measurements of ambient air concentrations in differently loaded regions of Leipzig, Fresen. J. Anal. Chem., 359, 189-197, 1997.

Kroll, J. H., Ng, N. L., Murphy, S. M., Flagan, R. C., and Seinfeld, J. H.: Secondary Organic Aerosol Formation from Isoprene Photooxidation, Environ. Sci. Technol., 40, 1869-1877, doi:10.1021/es0524301, 2006.

Langford, B., Nemitz, E., House, E., Phillips, G. J., Famulari, D., Davison, B., Hopkins, J. R., Lewis, A. C., and Hewitt, C. N.: Fluxes and concentrations of volatile organic compounds above central London, UK, Atmos. Chem. Phys., 10, 627-645, doi:10.5194/acp-10-627-2010, 2010.

Lanz, V. A., Hueglin, C., Buchmann, B., Hill, M., Locher, R., Staehelin, J., and Reimann, S.: Receptor modeling of C2-C7 hydrocarbon sources at an urban background site in Zurich, Switzerland: changes between 1993-1994 and 2005-2006, Atmos. Chem. Phys., 8, 2313-2332, doi:10.5194/acp-8-2313-2008, 2008.

Lee, A., Goldstein, A. H., Kroll, J. H., Ng, N. L., Varutbangkul, V., Flagan, R. C., and Seinfeld, J. H.: Gas-phase products and secondary aerosol yields from the photooxidation of 16 different terpenes, J. Geophys. Res., 111, D17305, doi:10.1029/2006JD007050, 2006a.

Lee, B. H., Munger, J. W., Wofsy, S. C., and Goldstein, A. H.: Anthropogenic emissions of nonmethane hydrocarbons in the northeastern United States: Measured seasonal variations from 1992-1996 and 1999-2001, J. Geophys. Res., 111, D20307, doi:10.1029/2005JD006172, 2006b.

Legreid, G., Balzani Lööv, J., Staehelin, J., Hueglin, C., Hill, M., Buchmann, B., Prevot, A. S., and Reimann, S.: Oxygenated volatile organic compounds (OVOCs) at an urban background site in Zürich (Europe): Seasonal variation and source allocation, Atmos. Environ., 41, 8409-8423, 2007.

Li, R., Palm, B. B., Borbon, A., Graus, M., Warneke, C., Ortega, A. M., Day, D. A., Brune, W. H., Jimenez, J. L., and De Gouw, J. A.: Laboratory Studies on Secondary Organic Aerosol Formation from Crude Oil Vapors, Environ. Sci. Technol., 47, 1256612574, doi:10.1021/es402265y, 2013.

Lim, Y. B. and Ziemann, P. J.: Products and Mechanism of Secondary Organic Aerosol Formation from Reactions of $n$-Alkanes with $\mathrm{OH}$ Radicals in the Presence of $\mathrm{NO}_{\mathrm{x}}$, Environ. Sci. Technol., 39, 9229-9236, doi:10.1021/es051447g, 2005.

Lim, Y. B. and Ziemann, P. J.: Effects of Molecular Structure on Aerosol Yields from $\mathrm{OH}$ Radical-Initiated Reactions of Linear, Branched, and Cyclic Alkanes in the Presence of $\mathrm{NO}_{\mathrm{x}}$, Environ Sci. Technol., 43, 2328-2334, doi:10.1021/es803389s, 2009a.

Lim, Y. B. and Ziemann, P. J.: Chemistry of Secondary Organic Aerosol Formation from OH Radical-Initiated Reactions of Linear, Branched, and Cyclic Alkanes in the Presence of $\mathrm{NO}_{\mathrm{x}}$, Aerosol Sci. Tech., 43, 604-619, 2009 b.

Loza, C. L., Craven, J. S., Yee, L. D., Coggon, M. M., Schwantes, R. H., Shiraiwa, M., Zhang, X., Schilling, K. A., Ng, N. L., Canagaratna, M. R., Ziemann, P. J., Flagan, R. C., and Seinfeld, J. H.: Secondary organic aerosol yields of 12-carbon alkanes, 
Atmos. Chem. Phys., 14, 1423-1439, doi:10.5194/acp-14-14232014, 2014.

Magill, P.L.: The Los Angeles Smog Problem, Ind. Eng. Chem., 41, 2476-2486, 1949.

Majumdar, D., Dutta, C., Mukherjee, A. K., and Sen, S.: Source apportionment of VOCs at the petrol pumps in Kolkata, India, exposure of workers and assessment of associated health risk, Transp. Res. D, 13, 524-530, 2008.

Martins, E. M., Arbilla, G., Bauerfeldt, G. F., and de Paula, M.: Atmospheric levels of aldehydes and BTEX and their relationship with vehicular fleet changes in Rio de Janeiro urban area, Chemosphere, 67, 2096-2103, 2007.

Michoud, V., Kukui, A., Camredon, M., Colomb, A., Borbon, A., Miet, K., Aumont, B., Beekmann, M., Durand-Jolibois, R., Perrier, S., Zapf, P., Siour, G., Ait-Helal, W., Locoge, N., Sauvage, S., Afif, C., Gros, V., Furger, M., Ancellet, G., and Doussin, J.-F.: Radical budget analysis in a suburban European site during the MEGAPOLI summer field campaign, Atmos. Chem. Phys., 12, 11951-11974, doi:10.5194/acp-12-11951-2012, 2012.

Michoud, V., Colomb, A., Borbon, A., Miet, K., Beekmann, M., Camredon, M., Aumont, B., Perrier, S., Zapf, P., Siour, G., AitHelal, W., Afif, C., Kukui, A., Furger, M., Dupont, J. C., Haeffelin, M., and Doussin, J. F.: Study of the unknown HONO daytime source at a European suburban site during the MEGAPOLI summer and winter field campaigns, Atmos. Chem. Phys., 14, 2805-2822, doi:10.5194/acp-14-2805-2014, 2014.

Molina, M. J. and Molina, L. T.: Megacities and atmospheric pollution, J. Air Waste Manage. Assoc., 54, 644-680, 2004.

Monod, A., Sive, B. C., Avino, P., Chen, T., Blake, D. R., and Rowland, F. S.: Monoaromatic compounds in ambient air of various cities: a focus on correlations between the xylenes and ethylbenzene, Atmos. Environ., 35, 135-149, 2001.

$\mathrm{Na}, \mathrm{K}$. and Kim, Y. P.: Seasonal characteristics of ambient volatile organic compounds in Seoul, Korea, Atmos. Environ., 35, 26032614, 2001.

Nelson, P. F. and Quigley, S. M.: The m,p-xylenes:ethylbenzene ratio. A technique for estimating hydrocarbon age in ambient atmospheres, Atmos. Environ., 17, 659-662, 1983.

Ng, N. L., Kroll, J. H., Chan, A. W. H., Chhabra, P. S., Flagan, R. C., and Seinfeld, J. H.: Secondary organic aerosol formation from m-xylene, toluene, and benzene, Atmos. Chem. Phys., 7, 3909-3922, doi:10.5194/acp-7-3909-2007, 2007a.

Ng, N. L., Chhabra, P. S., Chan, A. W. H., Surratt, J. D., Kroll, J. H., Kwan, A. J., McCabe, D. C., Wennberg, P. O., Sorooshian, A., Murphy, S. M., Dalleska, N. F., Flagan, R. C., and Seinfeld, J. H.: Effect of $\mathrm{NO}_{\mathrm{x}}$ level on secondary organic aerosol (SOA) formation from the photooxidation of terpenes, Atmos. Chem. Phys., 7, 5159-5174, doi:10.5194/acp-7-5159-2007, 2007b.

Novelli, P. C., Collins, J. E., Myers, R. C., Sachse, G. W., and Scheel, H. E.: Reevaluation of the NOAA/CMDL carbon monoxide reference scale and comparisons with $\mathrm{CO}$ reference gases at NASA-Langley and the Fraunhofer Institut, J. Geophys. Res., 99, 12833-12839, doi:10.1029/94JD00314, 1994.

Odum, J. R., Jungkamp, T. P. W., Griffin, R. J., Flagan, R. C., and Seinfeld, J. H.: The Atmospheric Aerosol-Forming Potential of Whole Gasoline Vapor, Science, 276, 96-99, 1997.

Pankow, J. F.: An absorption model of the gas/aerosol partitioning involved in the formation of secondary organic aerosol, Atmos. Environ., 28, 189-193, 1994.
Park, R. J., Jacob, D. J., Chin, M., and Martin, R. V.: Sources of carbonaceous aerosols over the United States and implications for natural visibility, J. Geophys. Res., 108, 4355, doi:10.1029/2002JD003190, 2003.

Parrish, D.D., Trainer, M., Young, V., Goldan, P. D., Kuster, W. C., Jobson, B. T., Fehsenfeld, F. C., Lonneman, W. A., Zika, R. D., Farmer, C. T., Riemer, D. D., and Rodgers, M. O.: Internal consistency tests for evaluation of measurements of anthropogenic hydrocarbons in the troposphere, J. Geophys. Res., 103, 22339 22359, doi:10.1029/98JD01364, 1998.

Presto, A. A., Miracolo, M. A., Donahue, N. M., and Robinson, A. L.: Secondary Organic Aerosol Formation from High- $\mathrm{NO}_{\mathrm{x}}$ Photo-Oxidation of Low Volatility Precursors: $n$-Alkanes, Environ. Sci. Technol., 44, 2029-2034, doi:10.1021/es903712r, 2010.

Pye, H. O. T. and Pouliot, G. A.: Modeling the Role of Alkanes, Polycyclic Aromatic Hydrocarbons, and Their Oligomers in Secondary Organic Aerosol Formation, Environ. Sci. Technol., 46, 6041-6047, doi:10.1021/es300409w, 2012.

Ran, L., Zhao, C. S., Xu, W. Y., Lu, X. Q., Han, M., Lin, W. L., Yan, P., Xu, X. B., Deng, Z. Z., Ma, N., Liu, P. F., Yu, J., Liang, W. D., and Chen, L. L.: VOC reactivity and its effect on ozone production during the HaChi summer campaign, Atmos. Chem. Phys., 11, 4657-4667, doi:10.5194/acp-11-4657-2011, 2011.

Roberts, J. M., Fehsenfeld, F. C., Liu, S. C., Bollinger, M. J., Hahn, C., Albritton, D. L., and Sievers, R. E.: Measurements of aromatic hydrocarbon ratios and $\mathrm{NO}_{\mathrm{x}}$ concentrations in the rural troposphere: Observation of air mass photochemical aging and $\mathrm{NO}_{\mathrm{x}}$ removal, Atmos. Environ., 18, 2421-2432, 1984.

Robinson, A. L., Donahue, N. M., Shrivastava, M. K., Weitkamp, E. A., Sage, A. M., Grieshop, A. P., Lane, T. E., Pierce, J. R., and Pandis, S. N.: Rethinking Organic Aerosols: Semivolatile Emissions and Photochemical Aging, Science, 315, 1259-1262, 2007.

Roukos, J., Riffault, V., Locoge, N., and Plaisance, H.: VOC in an urban and industrial harbor on the French North Sea coast during two contrasted meteorological situations, Environ. Poll., 157, 3001-3009, 2009.

Russo, R. S., Zhou, Y., White, M. L., Mao, H., Talbot, R., and Sive, B. C.: Multi-year (2004-2008) record of nonmethane hydrocarbons and halocarbons in New England: seasonal variations and regional sources, Atmos. Chem. Phys., 10, 4909-4929, doi:10.5194/acp-10-4909-2010, 2010.

Sauvage, S., Plaisance, H., Locoge, N., Wroblewski, A., Coddeville, P., and Galloo, J.C.: Long term measurement and source apportionment of non-methane hydrocarbons in three French rural areas, Atmos. Environ., 43, 2430-2441, 2009.

Schauer, J. J., Kleeman, M. J., Cass, G. R., and Simoneit, B. R. T.: Measurement of Emissions from Air Pollution Sources. 2. C1 through C30 Organic Compounds from Medium Duty Diesel Trucks, Environ. Sci. Technol., 33, 1578-1587, doi:10.1021/es980081n, 1999a.

Schauer, J. J., Kleeman, M. J., Cass, G. R., and Simoneit, B. R. T.: Measurement of Emissions from Air Pollution Sources. 1. C1 through C29 Organic Compounds from Meat Charbroiling, Environ. Sci. Technol., 33, 1566-1577, doi:10.1021/es980076j, 1999b.

Schauer, J. J., Kleeman, M. J., Cass, G. R., and Simoneit, B. R. T.: Measurement of Emissions from Air Pollution Sources. 3. C1C29 Organic Compounds from Fireplace Combustion of Wood, 
Environ. Sci. Technol., 35, 1716-1728, doi:10.1021/es001331e, 2001.

Schauer, J. J., Kleeman, M. J., Cass, G. R. and Simoneit, B. R. T.: Measurement of Emissions from Air Pollution Sources. 5. C1-C32 Organic Compounds from GasolinePowered Motor Vehicles, Environ. Sci. Technol., 36, 1169-1180, doi:10.1021/es0108077, 2002.

Sciare, J., d'Argouges, O., Zhang, Q. J., Sarda-Estève, R., Gaimoz, C., Gros, V., Beekmann, M., and Sanchez, O.: Comparison between simulated and observed chemical composition of fine aerosols in Paris (France) during springtime: contribution of regional versus continental emissions, Atmos. Chem. Phys., 10, 11987-12004, doi:10.5194/acp-10-11987-2010, 2010.

Seinfeld, J. H. and Pandis, S. N.: Atmospheric Chemistry and Physics, John Wiley, Hoboken, NJ, New York, 700-765, 1998.

Shao, M., Zhao, M., Zhang, Y., Peng, L., and Li, J.: Biogenic vocs emissions and its impact on ozone formation in major cities of China, J. Environ. Sci. Heal. A, 35, 1941-1950, 2000.

Shirai, T., Yokouchi, Y., Blake, D. R., Kita, K., Izumi, K., Koike, M., Komazaki, Y., Miyazaki, Y., Fukuda, M., and Kondo, Y.: Seasonal variations of atmospheric C2-C7 nonmethane hydrocarbons in Tokyo, J. Geophys. Res., 112, D24305, doi:10.1029/2006JD008163, 2007.

Sin, D. W. M., Wong, Y.-C., and Louie, P. K. K.: Trends of ambient carbonyl compounds in the urban environment of Hong Kong, Atmos. Environ., 35, 5961-5969, 2001.

Sjostedt, S. J., Slowik, J. G., Brook, J. R., Chang, R. Y.-W., Mihele, C., Stroud, C. A., Vlasenko, A., and Abbatt, J. P. D.: Diurnally resolved particulate and VOC measurements at a rural site: indication of significant biogenic secondary organic aerosol formation, Atmos. Chem. Phys., 11, 5745-5760, doi:10.5194/acp-11-57452011, 2011.

So, K. L. and Wang, T.: C3-C12 non-methane hydrocarbons in subtropical Hong Kong: spatial-temporal variations, source-receptor relationships and photochemical reactivity, Sci. Total Environ., 328, 161-174, 2004.

Srivastava, A.: Source apportionment of ambient VOCS in Mumbai city, Atmos. Environ., 38, 6829-6843, 2004.

Srivastava, A., Joseph, A. E., More, A., and Patil, S.: Emissions of VOCs at Urban Petrol Retail Distribution Centres in India (Delhi and Mumbai), Environ. Monit. Assess., 109, 227-242, 2005.

Stohl, A., Forster, C., Frank, A., Seibert, P., and Wotawa, G.: Technical note: The Lagrangian particle dispersion model FLEXPART version 6.2, Atmos. Chem. Phys., 5, 2461-2474, doi:10.5194/acp-5-2461-2005, 2005.

Swanson, A.L., Blake, N. J., Atlas, E., Flocke, F., Blake, D. R. and Sherwood, R., F.: Seasonal variations of C2-C4 nonmethane hydrocarbons and C1-C4 alkyl nitrates at the Summit research station in Greenland, J. Geophys. Res., 108, 4065, doi:10.1029/2001JD001445, 2003.

Tanaka, P. L., Riemer, D. D., Chang, S., Yarwood, G., McDonaldBuller, E. C., Apel, E. C., Orlando, J. J., Silva, P. J., Jimenez, J. L., Canagaratna, M. R., Neece, J. D., Mullins, C., and Allen, D. T.: Direct evidence for chlorine-enhanced urban ozone formation in Houston, Texas, Atmos. Environ., 37, 1393-1400, 2003.

Tkacik, D. S., Presto, A. A., Donahue, N. M., and Robinson, A. L.: Secondary Organic Aerosol Formation from Intermediate-Volatility Organic Compounds: Cyclic, Linear, and
Branched Alkanes, Environ. Sci. Technol., 46, 8773-8781, doi:10.1021/es301112c, 2012.

Tse, C. W., Flagan, R. C., and Seinfeld, J. H.: Rate constants for the gas-phase reaction of the hydroxyl radical with a series of dimethylbenzaldehydes and trimethylphenols at atmospheric pressure, Int. J. Chem. Kinet., 29, 523-525, 1997.

United Nations: World urbanization Prospects, the 2011 Revision., available at: http://esa.un.org/unup/CD-ROM/ Urban-Agglomerations.htm (last access: October 2012), 2012.

Velasco, E., Lamb, B., Westberg, H., Allwine, E., Sosa, G., ArriagaColina, J. L., Jobson, B. T., Alexander, M. L., Prazeller, P., Knighton, W. B., Rogers, T. M., Grutter, M., Herndon, S. C., Kolb, C. E., Zavala, M., De Foy, B., Volkamer, R., Molina, L. T., and Molina, M. J.: Distribution, magnitudes, reactivities, ratios and diurnal patterns of volatile organic compounds in the Valley of Mexico during the MCMA 2002 \& 2003 field campaigns, Atmos. Chem. Phys., 7, 329-353, doi:10.5194/acp-7-329-2007, 2007.

Volkamer, R., Jimenez, J. L., San Martini, F., Dzepina, K., Zhang, Q., Salcedo, D., Molina, L. T., Worsnop, D. R. and Molina, M. J.: Secondary organic aerosol formation from anthropogenic air pollution: Rapid and higher than expected, Geophys. Res. Lett., 33, L17811, doi:10.1029/2006GL026899, 2006.

von Schneidemesser, E., Monks, P. S. and Plass-Duelmer, C.: Global comparison of VOC and CO observations in urban areas, Atmos. Environ., 44, 5053-5064, 2010.

Wang, H.-K., Huang, C.-H., Chen, K.-S., and Peng, Y.-P.: Seasonal Variation and Source Apportionment of Atmospheric Carbonyl Compounds in Urban Kaohsiung, Taiwan, Aerosol Air Qual. Res., 10, 559-570, 2010.

Warneke, C., McKeen, S. A., de Gouw, J. A., Goldan, P. D., Kuster, W. C., Holloway, J. S., Williams, E. J., Lerner, B. M., Parrish, D. D., Trainer, M., Fehsenfeld, F. C., Kato, S., Atlas, E. L., Baker, A., and Blake, D. R.: Determination of urban volatile organic compound emission ratios and comparison with an emissions database. J. Geophys. Res., 112, D10S47, doi:10.1029/2006JD007930, 2007.

Warneke, C., De Gouw, J. A., Holloway, J. S., Peischl, J., Ryerson, T. B., Atlas, E., Blake, D., Trainer, M., and Parrish, D. D.: Multiyear trends in volatile organic compounds in Los Angeles, California: Five decades of decreasing emissions, J. Geophys. Res., 117, D00V17, doi:10.1029/2012JD017899, 2012.

Wildt, J., Kobel, K., Schuh-Thomas, G., and Heiden, A. C.: Emissions of Oxygenated Volatile Organic Compounds from Plants Part II: Emissions of Saturated Aldehydes, J. Atmos. Chem., 45, 173-196, 2003.

Yang, K.-L., Ting, C.-C., Wang, J.-L., Wingenter, O. W., and Chan, C.-C.: Diurnal and seasonal cycles of ozone precursors observed from continuous measurement at an urban site in Taiwan, Atmos. Environ., 39, 3221-3230, 2005.

Yoshino, A., Nakashima, Y., Miyazaki, K., Kato, S., Suthawaree, J., Shimo, N., Matsunaga, S., Chatani, S., Apel, E., Greenberg, J., Guenther, A., Ueno, H., Sasaki, H., ya Hoshi, J., Yokota, H., Ishii, K., and Kajii, Y.: Air quality diagnosis from comprehensive observations of total $\mathrm{OH}$ reactivity and reactive trace species in urban central Tokyo, Atmos. Environ., 49, 51-59, 2012.

Yuan, B., Hu, W. W., Shao, M., Wang, M., Chen, W. T., Lu, S. H., Zeng, L. M., and Hu, M.: VOC emissions, evolutions and contributions to SOA formation at a receptor site in eastern China, 
Atmos. Chem. Phys., 13, 8815-8832, doi:10.5194/acp-13-88152013, 2013.

Zhang, Q., Worsnop, D. R., Canagaratna, M. R., and Jimenez, J. L.: Hydrocarbon-like and oxygenated organic aerosols in Pittsburgh: insights into sources and processes of organic aerosols, Atmos. Chem. Phys., 5, 3289-3311, doi:10.5194/acp-5-32892005, 2005.

Zhang, Y. M., Zhang, X. Y., Sun, J. Y., Lin, W. L., Gong, S. L., Shen, X. J., and Yang, S.: Characterization of new particle and secondary aerosol formation during summertime in Beijing, China, Tellus B, 63, 382-394, 2011.
Zhang, Q. J., Beekmann, M., Drewnick, F., Freutel, F., Schneider, J., Crippa, M., Prevot, A. S. H., Baltensperger, U., Poulain, L., Wiedensohler, A., Sciare, J., Gros, V., Borbon, A., Colomb, A., Michoud, V., Doussin, J.-F., Denier van der Gon, H. A. C., Haeffelin, M., Dupont, J.-C., Siour, G., Petetin, H., Bessagnet, B., Pandis, S. N., Hodzic, A., Sanchez, O., Honoré, C., and Perrussel, O.: Formation of organic aerosol in the Paris region during the MEGAPOLI summer campaign: evaluation of the volatilitybasis-set approach within the CHIMERE model, Atmos. Chem. Phys., 13, 5767-5790, doi:10.5194/acp-13-5767-2013, 2013. 